\title{
Liposomal Drug Delivery: A Versatile Platform for Challenging Clinical Applications
}

Asadullah Madni ${ }^{1}$, Muhammad Sarfraz ${ }^{2}$, Mubashar Rehman ${ }^{1}$, Mahmood Ahmad ${ }^{1}$, Naveed Akhtar ${ }^{1}$, Saeed Ahmad ${ }^{1}$, Nayab Tahir $^{1}$, Shakeel Ijaz ${ }^{1}$, Raida Al-Kassas ${ }^{3}$ and Raimar Löbenberg ${ }^{2}$

${ }^{1}$ Department of Pharmacy, Faculty of Pharmacy \& Alternative Medicine, the Islamia University of Bahawalpur, Pakistan. ${ }^{2}$ Faculty of Pharmacy and Pharmaceutical Sciences, University of Alberta, Edmonton, Alberta, Canada. ${ }^{3}$ School of Pharmacy, Faculty of Medical and Health Sciences, University of Auckland, New Zealand.

Received, May 28, 2014; revised, June 6, 2014, accepted, August 1, 2014, Published August 3 ${ }^{\text {rd }} 2014$.

\begin{abstract}
Liposomes are lipid based vesicular systems that offer novel platform for versatile drug delivery to target cell. Liposomes were first reported by Bangham and his co-workers in 1964 (1). Since then, liposomes have undergone extensive research with the prime aim to optimize encapsulation, stability, circulation time and target specific drug delivery. Manipulation of a liposome's lipid bilayer and surface decoration with selective ligands has transformed conventional liposomes into adaptable and multifunctional liposomes. Development of liposomes with target specificity provide the prospect of safe and effective therapy for challenging clinical applications. Bioresponsive liposomes offer the opportunity to release payload in response to tissue specific microenvironment. Incorporation of novel natural and synthetic materials has extended their application from stable formulations to controlled release targeted drug delivery systems. Integration and optimization of multiple features into one system revolutionized research in the field of cancer, gene therapy, immunotherapy and infectious diseases. After 50 years since the first publication, this review is aimed to highlight next generation of liposomes, their preparation methods and progress in clinical applications.

This article is open to POST-PUBLICATION REVIEW. Registered readers (see "For Readers") may comment by clicking on ABSTRACT on the issue's contents page.
\end{abstract}

\section{INTRODUCTION}

Liposomes are lipid based vesicular systems in which a well-defined aqueous core is contained within a lipid bilayer. In May 1964, Alec D. Bangham and his colleagues reported spontaneously forming lipid vesicles and named them as "smectic mesophases" (1). These vesicle were named "Bangasomes" after the name of Bangham, the father of liposomes. In 1968, Weissmann coined a more descriptive term "liposomes", an analogy to the term lysosomes (2). Liposomes were initially used as membrane models in biological studies. However, the cell-like structure of liposomes persuaded scientist to investigate liposomes as a tool to smuggle potent drug molecules into human body. In 1971, first report was published on the liposomal encapsulation of a therapeutic agent (3). Liposomes can load hydrophilic drugs in aqueous core and increase penetration through lipophilic physiological membranes while lipophilic drugs are contained inside the lipid bilayer and increase their solubility in the aqueous body fluids (4). Liposome demonstrates better protection from external degradation caused by enzymes (5) and because they are prepared from natural materials or their synthetic derivatives, liposomes are biocompatible and biodegradable (6).

Conventional liposomes have some drawbacks. They are complex to produce, have less inherent stability and therefore, cannot be stored for a long time. Liposomes show rapid uptake by the reticuloendothelial system thus decreasing their circulation half-life. Leakage of loaded drugs from liposomes resulted in less drug loading efficiency. New materials and techniques employed in liposomal research may be toxic and non-biocompatible (7). Recently, it has been reported that repeated low dose injections may lead to accelerated blood clearance of liposome (8).

\footnotetext{
Corresponding Author: Dr. M. Asadullah Madni, Department of Pharmacy, Faculty of Pharmacy and Alternative Medicine, The Islamia University of Bahawalpur, Pakistan, E-Mail: asadpharmacist@hotmail.com
} 
To overcome these drawbacks, liposomes have undergone extensive research on surface modification, size optimization and understanding the disposition mechanism.

The next generation of liposomes is characterized by high mechanical stability, ability to induce or inhibit the immune system, longer circulation times, improved loading efficiency, enhanced penetration and target specificity. Accordingly, liposomes have emerged as promising carriers for sensitive drugs and macro molecules. Indeed, progress in pharmacology has introduced a number of potent therapeutic agents that require drug carriers that are selective and bio-responsive. This challenge to control drug release has been a milestone in the development of next generation liposomes. The improvements in liposomes include long circulating or stealth liposomes that have been prepared by decorating liposome surface with hydrophilic polymers such as polyethylene glycol which reduces liposomes uptake by the reticuloendothelial system (9) and toxicity of encapsulated drugs (10). Stealth liposomes have long circulation life and constitute an integral part of controlled release multifunctional liposomes. On the other hand, PEGylation or stealthing strongly inhibits cellular uptake of liposomes which limits its application in macrophage and tumor targeting. The problem has been addressed by the development of cleavable PEG systems that can detach PEG in response to target tissue microenvironment (11). A negative charged DNA can bind a positively charged lipid forming cationic liposomes with reduced size and increased circulation time (12). Targeted specificity is achieved by anchoring targeting ligands which bind to the desired receptors (13). The number of lamellae or crosslinking of lipid controls the drug release rate from liposomes (14). Different drugs can be loaded in different lamella that enables sequential release of drugs and simplifies the treatment regimen (15). Liposomal microarrays have been employed for the detection of proteins and peptides in different body fluids (16).

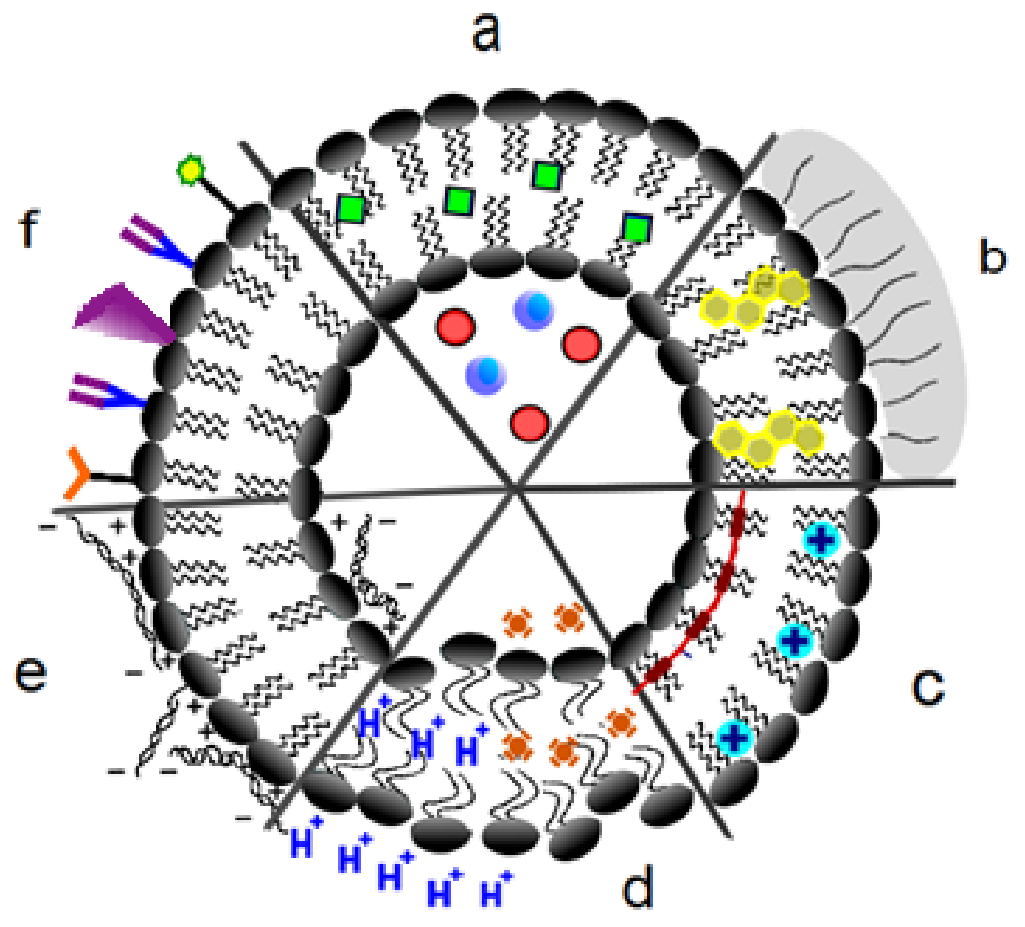

Figure 1: Multi-functionality of liposomes: (a) Encapsulation of hydrophilic drug (red) and gas bubbles (blue) into an aqueous core and entrapment of lipophilic drug (green) inside the bilayer, (b) Stabilization of lipid bilayer with cholesterol (yellow) and attachment of hydrophilic polymer layer on the bilayer surface, (c) Liposome lipid bilayer is strengthened and stabilized by polymerization (red) or by incorporation of multivalent cations (blue), (d) bio-responsive destabilization of lipid bilayer in acidic $\mathrm{pH}$ (blue) or increased temperature achieved by magnetic agents (Blue), (e) negatively charged DNA molecules are attached to positively charged lipid molecules, (f) attachment of immunogenic or targeting ligands on the liposome surface. 
Chimeric liposomes have been prepared by the combination of phospholipids with low quantities of other biomaterials to control physiochemical and structural properties of liposomes (17). Different imaging techniques and in silico models have been devised to predict or monitor biodistribution as well as quantitative structure-property relationship of liposomes (18-20).

Almost 50 years after the discovery of liposomes, the US FDA has approved 13 liposomes based products for human use (Table 1). In addition, a large number of liposomal products are in different phases of clinical trials $(21,22)$. The next generation of liposomes are prepared conventionally either by modification of conventional preparation methods or special laboratory techniques. Liposomes are prepared by a lipid hydration, ethanol injection, freeze-thawing and reverse phase evaporation. In the lipid hydration method, lipid is dissolved in an organic solvent followed by drying to form a thin lipid film. This lipid film is hydrated using an aqueous solution of a drug and vortexed to form liposome system. In the ethanol injection method, lipid is dissolved in ethanol and its solution injected into an aqueous buffer containing the drug. In the freezethawing method, a lipid film is hydrated with an aqueous buffer solution and subjected to repeated cycles of freezing and thawing thus yielding a liposome system. In the reverse phase evaporation technique, a solution of a lipid and an organic solvent is added to an aqueous buffer solution to form a water in oil emulsion. This emulsion is subjected to evaporation under low pressure which results in the formation of a liposome system. Researchers have also designed in-house laboratory scale detection methods for the characterization and quality control of liposomes (23). However, the scale-up of these sophisticated laboratory methods to industrial production still needs to be addressed. Major issues in industrial manufacturing of liposomes include the presence of residual organic solvent, difficulty of controlling liposome size distribution and stability problems associated with sterilization processes (24).

\section{ADVANCEMENT IN LIPOSOME TECHNOLOGY}

In this section, attempts have been made to reviews the next generation of liposomes, their preparation methods and progress in clinical applications.

Archeosomes: Archeosomes are liposomes made up of polar lipids of archaebacteria. Archaebacteria are extremophiles which can live in extremes of environment. Their cell membrane consists of etherlipids which differs from other eukaryotic and prokaryotic membrane lipids.

\begin{tabular}{|c|c|c|c|}
\hline Liposome Product & Active Ingredient & Liposome Type & Indication \\
\hline Ambisome & Amphotericin B & Liposome & Fungal Infections \\
\hline Abelcet & Amphotericin B & $\begin{array}{l}\text { Lipid Complex (not true } \\
\text { liposomes) }\end{array}$ & Fungal Infections \\
\hline Amphotec & Amphotericin B & $\begin{array}{l}\text { Lipid Complex (not true } \\
\text { liposomes) }\end{array}$ & Fungal Infections \\
\hline DaunoXome & Daunorubicin & Liposome & Blood Cancers \\
\hline Doxil & Doxorubicin & Stealth liposome & $\begin{array}{l}\text { Kaposi's Sarcoma, Ovarian and } \\
\text { Breast Cancer }\end{array}$ \\
\hline Lipo-dox & Doxorubicin & Stealth liposome & $\begin{array}{l}\text { Kaposi's Sarcoma, Ovarian and } \\
\text { Breast Cancer }\end{array}$ \\
\hline Marqibo & Vincristine & Nano-size liposome & Acute lymphoblastic leukaemia \\
\hline Myocet & Doxorubicin & Liposome & Metastatic breast cancer \\
\hline Visudyne & Verteporfin & Liposome & Photodynamic therapy \\
\hline Depocyt & Cytarabine & Liposome & $\begin{array}{l}\text { Neoplastic and lymphomatous } \\
\text { meningitis }\end{array}$ \\
\hline DepoDur & Morphine & Liposome & Pain management \\
\hline Epaxal & $\begin{array}{l}\text { Inactivated hepatitis } \mathrm{A} \\
\text { virus }\end{array}$ & Virosome & Hepatitis A \\
\hline Inflexal V & $\begin{array}{l}\text { Inactive hemaglutinine of } \\
\text { Influenza virus }\end{array}$ & Virosome & Influenza \\
\hline
\end{tabular}


The incorporation of inherently stable archae lipids, archaeol (diether) lipids and caldarchaeol (tetraether) lipids makes archeosomes resistant to $\mathrm{pH}$, temperature and oxidative stress (25-28). Tetraether lipids are bipolar unlike di-ether or other liposomal lipids which have one polar head (Figure 2). Additionally, ether lipids of bacterial origin are recognized as foreign substance by human immune system eliciting strong immunoadjuvant effects to the encapsulated vaccine.

Preparation: Polar lipids from archeobacterium are extracted by solvent extraction. High amount of detergent is added to the lipid followed by evaporation of the solvent. This lipid detergent mixture is dissolved in anaqueous buffer and detergent is removed by dialysis (29). Archeosomes can be prepared from these archeae lipids by lipid hydration method (30).

Applications: Archeosomes serve as carriers for vaccines to provide long circulation times. They can also act as adjutants for cell mediated immune responses (31-33). Tetraether archael lipidsare bipolar forming a stable archeosomes. Recent research has focused on manipulating synthetic analogues of archael ether lipids (34). The synthetic analogues facilitate the industrial production and purification of the finished product (35).

\section{Cochelates:}

Cochelates are cylindrical lipid bilayer assemblies prepared from preformed liposome in such a way that lipid bilayers of liposomes are stabilized with inorganic multivalent cations of zinc, calcium (36) and other organic multivalent cations (37). The multivalent cations act as bridging agent to hold lipid bilayers together which results in shrinkage of aqueous core (Figure 3). The unique solid structure of lipid bilayer is responsible for high mechanical strength and storage stability. The dried cochelates are stable at room temperature while cationic buffer solution of cochelate can be stored at $4^{\circ} \mathrm{C}$ for two years (38). In a similar study, multilamellar liposomes with covalently crosslinked lipid bilayers were reported for controlled release of anticancer drugs (10).

Preparation: Cochelates are prepared by two methods from preformed liposomes. Method 1: The solution of multivalent cations is added to the suspension of prepared liposomes followed by sonication. The milky suspension of liposomes is converted to colorless solution of nano cocheltes as sonication proceeds (37). Method 2 (Hydrogel method): Liposome are suspended in an aqueous two-phase polymer solution. Cations diffuse from one polymer phase to the other polymer phase containing liposomes which results in cochelates formations. The precipitate is washed with cationic buffer to remove the residual polymers (39).

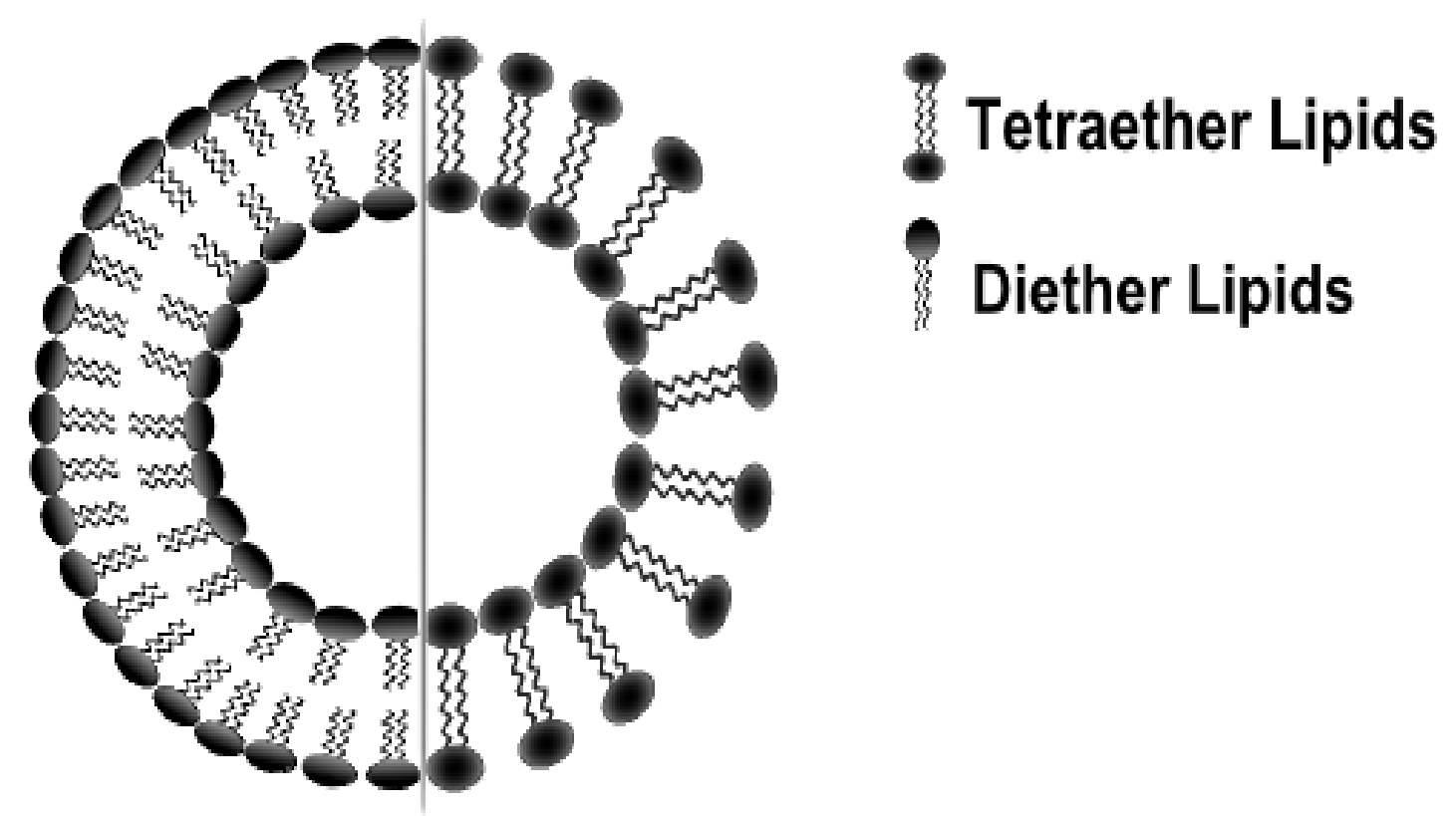

Figure 2: Archeosomes made from tetraether (bipolar) and diether lipids. 


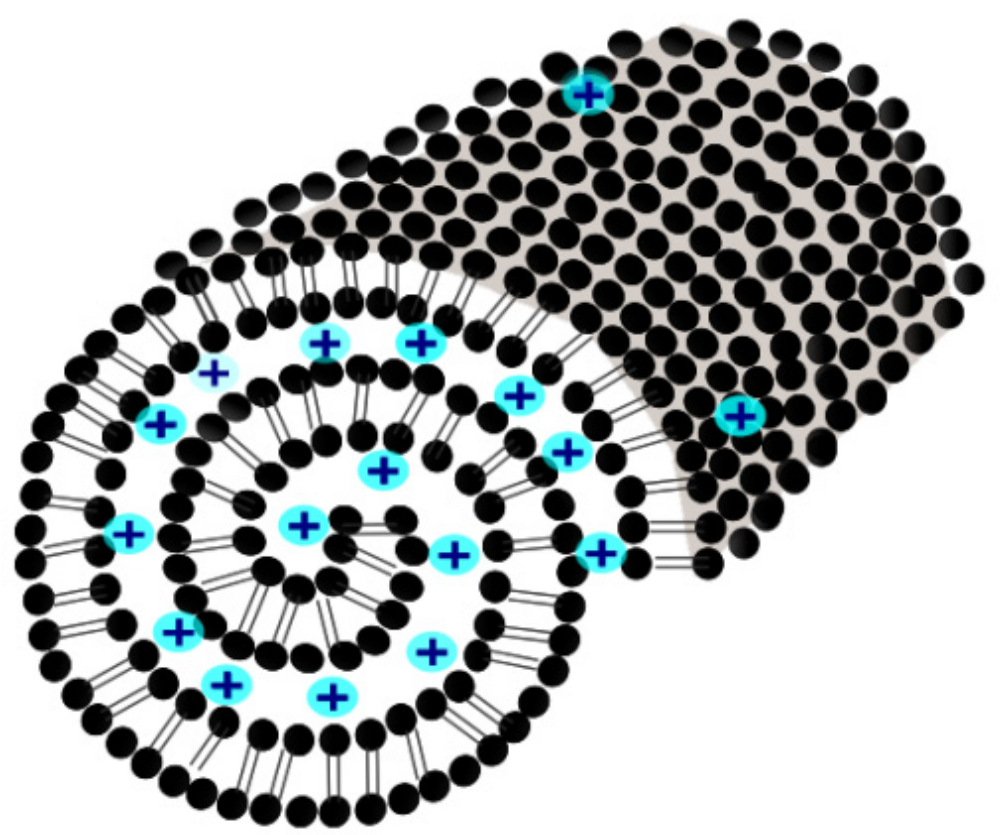

Figure 3: Incorporation of cations into lipid bilayer to improve stability.

Applications: Cochelates have been used for delivery of DNA and protein subunits. For mucosal and parenteral vaccine delivery, cochelates with virus antigen proteins are preferred over liposomes containing virus protein due to stronger immune response and longer circulation time (40). Oral cochelated Amphotericin B (CAMB) is 10 times more effective compared to conventional liposomes (41). Cochelates provide prolonged action of cationic antimicrobial peptides (AMPs) and alsocombat antibiotic resistance (42). In addition, presence of calcium cations in liposomes has been found to increase the fusion of fluid liposomes with bacterial cells thus enhancing the bactericidal activity in resistant strains (43).

\section{Cubosomes:}

Cubosomes are self-assembling cubic crystals of certain detergents with an intersecting network of water channels. Cubosomes do not fit properly under the strict definition of liposomes because they lack a well-defined aqueous core, but have attracted a vast research interest in lipid based drug delivery systems in the last decade $(44,45)$.

Preparation: Cubosomes are honeycomb like structures that are formed by dispersing amphiphilic lipids in the aqueous solution and a lipid bilayer is formed in three dimensional structures $(46,47)$.
Cubosomes have been developed by a fragmentation method and solvent precursor dilution method. In the fragmentation method, the lipids are heated above melting point in a glass vial and water $(25 \% \mathrm{w} / \mathrm{w}$ of lipid) is gently layered on to the surface of the lipid. This system is incubated for three days to allow the formation of cubosomes. Addition of stabilizer and a homogenization step may be required to get desired formulation (48). In the solvent precursor dilution method, lipid and stabilizer are first dissolved in ethanol. This modified lipid mixture is than dissolved completely in chloroform as lipid and solubilizer are soluble in it. Chloroform is evaporated under a stream of nitrogen $\left(\mathrm{N}_{2}\right)$ and $10 \mathrm{uL}$ aqueous drug solution is added to the lipid mixture. The liquid precursors are dispersed in deionized water with continuous stirring for 10 minutes (49).

Applications: Cubosomes have been used for oral, parenteral, topically and ocular administration. Dexamethasone cubosomes for ophthalmic use are four to five times more effective than eye drops. Cubosomes have also demonstrated superior peptide delivery properties over liposomes, transferosomes and ethosomes (50). Recent research has demonstrated their successful application in the treatment of cancer $(51,52)$. In addition, cubosomes are used for delivery of 
vaccines (48) and diagnostics and separation techniques (53). Although the reports of therapeutic applications of cubosomes are increasing, there is negligible data on the cytotoxicity of cubosomes. Further studies are required on cubosomes toxicity to justify their application in medical field (54).

\section{Ethosomes:}

Ethosomes are transdermal liposomes containing hydroalcoholic core for enhanced penetration through the stratum corneum and other skin layers (Figure 4). The presence of ethanol in core increases fluidity and penetration of ethosomes bilayer without affecting its stability. Ethosomes enhance transdermal delivery of drug by enhanced permeation in terms of depth and deposition behavior (55). Ethosomes are more effective in nanometer range and provide a noninvasive mean for enhancing skin permeation (56-60).

Preparation: Hot and cold methods have been employed for ethosomes preparation. In the hot method, phospholipids are dispersed in water at $40^{\circ} \mathrm{C}$. Drug is dissolved in ethanol and propylene glycol and this mixture is added into the phospholipids solution using magnetic stirring. In the cold method, phospholipids and drug are dissolved in ethanol and heated to $30^{\circ} \mathrm{C}$. This mixture is added to the water maintained at $30^{\circ} \mathrm{C}$. The ethosomes suspension is sonicated and extruded to produce homogeneous ethosomes $(60,61)$.
Applications: Ethosomes serves as carriers for transcutaneous immunization (62) and gene delivery (63). These are also employed for antiinflammatory $(64,65)$, anti-psoriatic $(66)$ and antimicrobial therapeutics (67). Recent research has focused on binary ethosomes that contain polyols (such as propylene glycol) in addition to alcohol and water inside the ethosome core. Ethosomes and binary ethosomes have demonstrated superior penetration efficiency over conventional liposomes, transferosomes and other specialized drug delivery systems (68-71).

\section{Exosomes:}

Exosomes are phospholipid vesicles released by normal and tumor cells. In normal cells, they control cell-to-cell communication by paracrine signals to induce protein synthesis and alter the behavior and proliferation of surrounding cells. In tumor cells, they help in maintaining a tumor specific environment by paracrine signaling for promoting angiogenesis and lymphocyte apoptosis. These tumor derived exosomes have been isolated from patients and loaded with anticancer agents for individualized therapy of cancer. Their surface complexity and non-specificity hindered their use in drug delivery systems and trigger the development of exosome-mimetic, liposomes with functional components of exosomes (72-74). The endogenous origin of exosomes is advantageous over synthetic nanocarriers due to excellent biocompatibility and targeting potential (75).
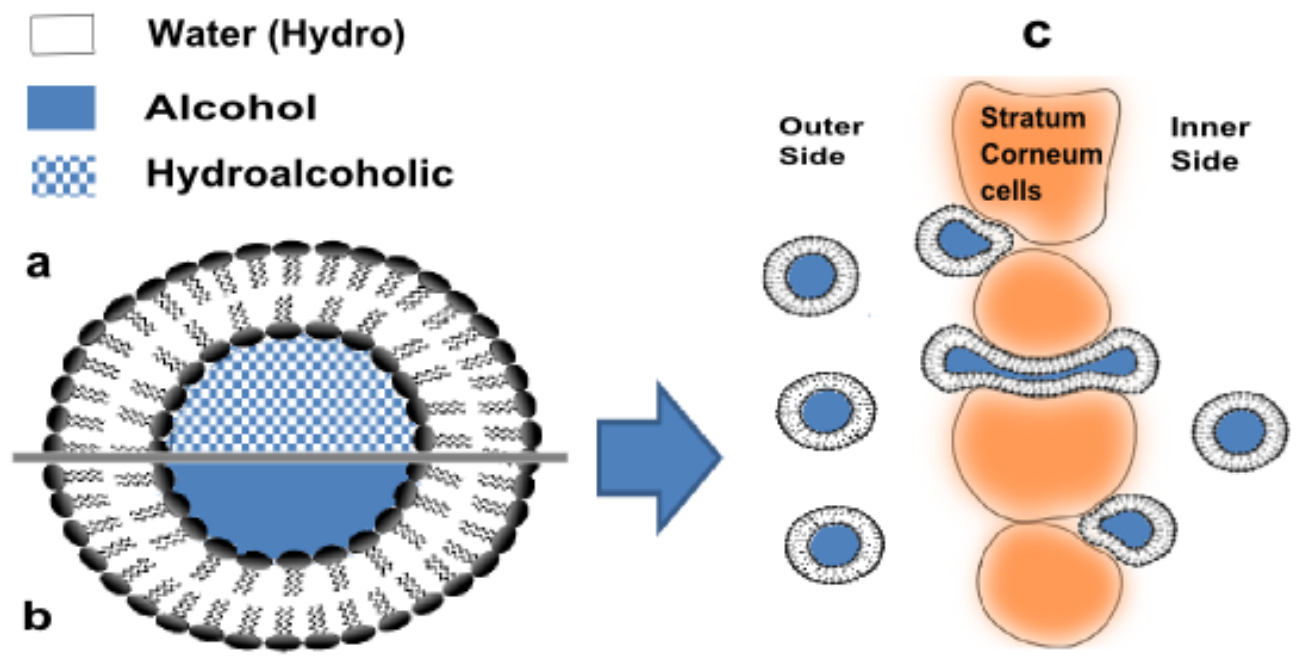

Figure 4: (a) Ethosomes with hydro-alcoholic (water and alcohol) core (b) Ethosomes with alcoholic core. (c) Passage of the ethosomes from outside the skin, through very small pores, into the inner site of the stratum corneum. 
Preparation: Exosomes secreting cells are immortalized in vitro and exosomes are separated by differential centrifugation. Therapeutic agents are loaded into prepared exosomes by standard transfection techniques such as electroporation or lipofection. Electroporation is a physical method in which successive electric impulses are applied on exosomes which increase their permeability and entrapment of DNA molecules. Colloidal stability of exosomes after electroporation should be given keen consideration which is function of composition of media, exosomes concentration and charge applied (76). Lipofection is a chemical techniques in which positively charged lipids bind negatively charged DNA molecules (77).

Applications: Exosomes are employed for the delivery of genes because of their intrinsic ability to cross biological barriers and their non-immunogenic nature (78). Suppression of the immune system by cancerous exosomes has been assumed to treat autoimmune diseases (77). Some researchers are thus focusing on targeted cancer vaccination and individualizing therapy with patient derived exosomes $(79,80)$.

\section{Gas containing liposomes:}

These liposomes are modified to encapsulate a gas bubble that contains gas up to $80 \%$ of their inner capacity $(81,82)$. Liposomes loaded with chemical agents such as ammonium chloride produce gas bubbles and cause the release of loaded therapeutic moiety (83). Targeted gas containing liposomes are currently being investigated for deep tissue tumor diagnosis (84).

Preparation: Gas containing liposomes are prepared by the film hydration and freeze thawing method. The process is carried out in the presence of gas to be encapsulated under high pressure (84).

Applications: Targeted gaseous liposomes are employed for tumor tissue detection. These liposomes oscillate under low frequency ultrasound thereby producing a characteristic echo which is different from the echo of surrounding tissues (81). Therapeutic drug molecules loaded to gas containing liposomes release the drug at a controlled rate by applying specific ultrasound frequency outside the body region (82). Nitric oxide containing liposomes have been used to induce relaxation of the vascular smooth muscles (83). Xenon gas is reported to be an effective and nontoxic neuroprotectant agent when encapsulated in gaseous liposomes (85).

\section{Immunoliposomes:}

Surface ligands such as monoclonal antibodies when attached to the liposomes are effectively targeted to different body tissues (86). Immunoliposomes selectively bind to a receptor of target cell and become internalized, thereby increasingthe bioavailability of therapeutics. These Immunoliposomes confine the action of very toxic and/or potent pharmacological agents at target tissues and safeguard other body tissues from unnecessary exposure (86-88). Development of the immunoliposomes in the $1980 \mathrm{~s}$ provided a milestone in the evolution of advanced multifunctional liposomes (Figure 5).

Preparation: Antibodies or antibody fragments are conjugated on liposome surface by mixing isolated antibody fragments with already prepared cationic liposomes. These immune-cationic liposomes are then mixed with therapeutic drug solution to form a drug-loaded immunoliposomes (89). Recently, folate conjugated immunoliposomes have been prepared by one step microfluidic synthesis. In this method, folate conjugated phospholipid are passed through thermoplastic microfluidic device in a controlled laminar flow. This method can produce immunoliposomes in nano size range (90).

Applications: Various monoclonal antibodies produced against different cancerous tissues have been used in cancer chemotherapy by formulating immunoliposomes. Multifunctional immuoliposomes have long circulation time and can carry more than one therapeutic and diagnostic agents (91). Immunoliposomes have successfully been targeted to tumor cells (9295), vascular endothelium (96) and infarcted heart tissue (97). Immunoliposome are meant to improve safety profile of potent drugs by limiting drug exposure to target sites but recently reported results of Shmeeda et al., (2013) found that liposomal zoledronic acid was almost 50 times more toxic than free zoledronic acid solution. 


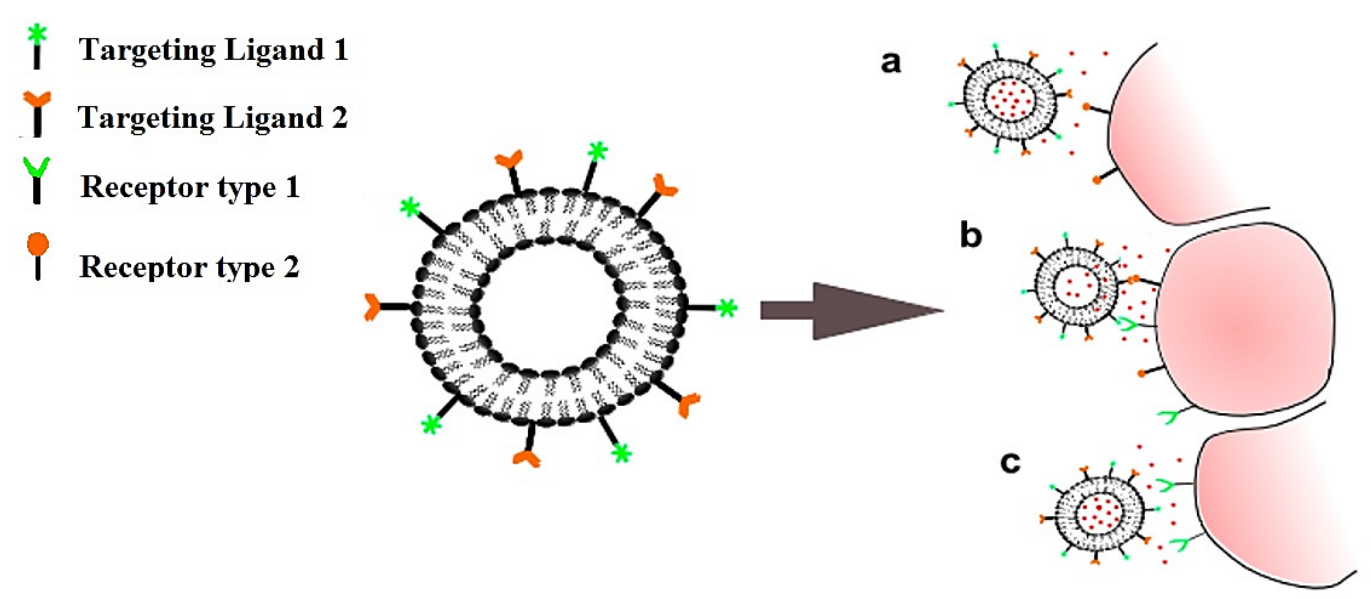

Figure 5: Bi-specific targeting by attachment of two different ligands; Immunoliposomes attached to receptors for targeting both ligands simultaneously. Immunoliposomes can bind and release drugs at tumor cells expressing any one receptor type (a) and (c) or both receptors simultaneously.

Toxicity was found to be dose dependent and attributed to unexpectedly high macrophages activation (98). However, this enhanced toxicity might underlie entirely different mechanism because liposomal drugs, such as cisplatin, have been found to act differently than free drug at molecular level (99). Current research is focused on developing bispecific ligands for dual targeting of tumor cells with more specificity (100). Moreover, liposomes displaying antigenic proteins and glycan ligands for the inhibitory co-receptor CD22 have been reported to elicit only antigen specific immune response and prevent $\mathrm{B}$ cell mediated harmful immune responses (101). Harmful immune and inflammatory response to immunostimulatory agents can also be prevented by localized immunotherapy. One such strategy is the intratumoral injection of controlled size liposomes which allows dissemination of liposomal drugs into tumor tissue and tumor draining lymph nodes but prevents entry into systemic circulation due to large size of liposomes (102).

\section{Immunosomes and Virosomes:}

Immunosomes are prepared by attaching viral glycoproteins on liposome lipid bilayer. Immunosomes are nano-sized globular particles having uniform glycoprotein attachments (50-60 $\mathrm{nm})$ (103-105). Immunosomes are non-toxic vaccine carriers with strong immuno-adjuvant properties to stimulate or inhibit the humoral as well as cell mediated immunity. Research on immunosomes has led to the discovery of virosomes. Virosomes are substituted viral coats of lipids, glycoproteins, haemagglutinin and other antigenic components. Virosomes lack viral nucleic material and fail to replicate (106). Immunosomes differ from virosomes in their composition. Immunosomes are a type of liposomes that contain only certain isolated antigens of a virus while virosomes are complete virus shells with all viral lipids, glycoprotein and antigenic determinants (Figure 6). Usually, these terms are used interchangeably but the term virosome is preferred over immunosome to avoid any confusion with immunoliposomes. The surface fastened viral glycoproteins provide an indistinguishable structure to immunosome and virosome and is responsible for their immunogenic properties similar to the parent virus (107).

Preparation: Using the detergent solubilizing method, immunosomes are prepared by mixing viral surface proteins with liposomes. Virus hemagglutinin is prepared by solubilizing the virus cell with a $10 \mathrm{nM}$ HEPES saline solution followed by centrifugation that separates the virus hemagglutinin. Its purified rosette is mixed with liposomes and incubated at $37^{\circ} \mathrm{C}$ for $30 \mathrm{~min}$ $(105,108)$. Stability of immunoliposomes is also dependent upon the interaction between phospholipid head groups and viral proteins. Immunosomes consisting of binary lipid mixtures are more stable as compared to liposomes composed of single lipid type (109). 

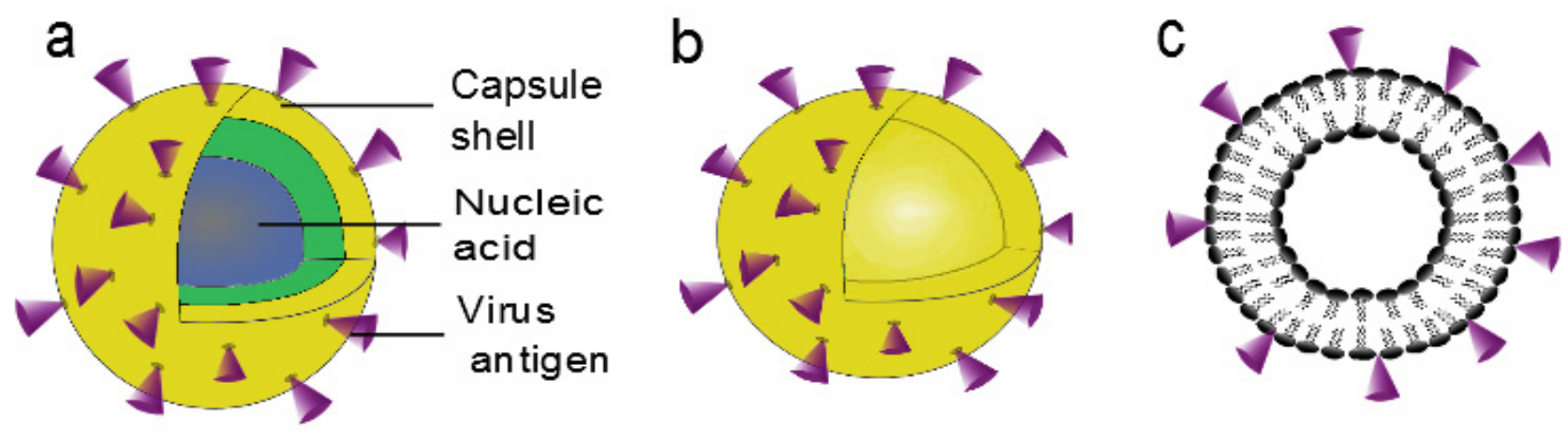

Figure 6. (a) The whole influenza virus is converted into a virosome (b) The virosome retains only the outer shell and associated antigens. The immunosome is prepared by attaching virus glycoproteins antigens on the liposome surface (c).

Application: Immunosomes and virsomes are vaccine carriers with strong adjuvant propertiesagainst AIDS, influenza, hepatitis and rabies viruses in mice. These carrier vaccines have also proved to be effective against these viral strains in ex-vivo and animal studies (110-114). The vaccines Epaxal (Hepatitis A) and Inflexal (Influenza) are already available for clinical use (Table 1).

\section{Immune stimulating complexes (ISCOMs)}

ISCOMs are vaccine adjuvants which induce a wide range of antibodies by humoral activation as well as strong cell mediated responses against antigen. Major structural components of ISCOMs are cholesterol, phospholipids and quiallaja saponins (Quil A). They contain amphiphilic antigens like membrane proteins and in aqueous solution can be stored for years at cool temperature (115).

Preparation: ISCOMs are prepared by ether injection method. Phospholipids and cholesterol are dissolved in ether and injected into aqueous solution containing Quil A. An optimal ratio $(5: 3: 2)$ of Phospholipids, Quil A and cholesterol and injection rate ensures homogenous preparation (116).

Applications: Immune stimulating complexes produce a wide range of antibodies by humoral and cell mediated responses making them a carrier of choice for vaccines against intracellular and chronic infections (117). Posintro ${ }^{\mathrm{TM}}$ denotes a new generation of ISCOMs with modified surface charge for enhanced penetration through the skin. Incorporation of positively charged cholesterol derivatives and DC-cholesterol reduces overall negative charge of the lipid bilayer. Thus, Posintro ${ }^{\mathrm{TM}}$ may follow the intracellular pathway of absorption by disrupting the stratum corneum (118).

\section{Lipoplexes}

Lipoplexes are formed when cationic lipids are coupled with a negatively charge of DNA molecules. Lipoplexes are considered toxic due to the presence of cationic lipids. Toxicity can be reduced by using compact plasmid DNA (pDNA). When an elongated DNA is transformed into a compact form, its overall negative charge decreases and lesser amount of cationic lipid is needed (119122). Effective lipoplex formulations require optimization of size and structure of the selfassembled vesicles (123). Major disadvantage of lipoplexes is acute inflammatory response after administration. The sequential administration of plasmid DNA and lipoplexes as repeated doses has been found to minimize the acute inflammation and other lipoplexes associated toxicities (124).

Preparation: $p$ DNA is isolated from purified plasmid using suitable techniques. Cationic liposomes are prepared by lipid hydration and sonicated until a clear translucent solution is formed. The $p$ DNA solution is added to cationic liposomes and mixed gently. The obtained lipoplexes suspensions is stored at room temperature for 15-30 min before use (125).

Applications: Lipoplexes are used for viral DNA transfection avoiding virus associated immunogenicity and oncogenecity. Lipoplexes are 
easier to produce compared to other viral carrier preparations (126-127). Incorporation of co-lipids such as dioleyl phosphatidylethanolamine (DOPE), cholesterol and some fatty acids have been reported to increase gene transfection rates. Co-lipids make lipoplexes more rigid and increase their size which facilitates their fusion with cell membranes and phagocytosis. Lipoplexes may also act as immuneadjuvant when admixed with protein antigens. However, their adjuvant activity is primarily due to enhanced uptake of proteins by antigen presenting cells as compared to negatively charged liposomes that promote activation and maturation of antigen presenting cells (128). Recent research has focused on making lipoplexes more plasma friendly, optimizing morphological features which can control cellular uptake and intracellular disposition (129-130). The manipulation of co-lipids has led to improved transfection efficiency (131-132) and targeted delivery (133).

\section{Magnetic liposomes:}

These are the type of advanced liposomes which contain magnetic or paramagnetic entities such as gadolinium $\left(\mathrm{Gd}^{3+}\right)$ and Iron $\left(\mathrm{Fe}^{3+} / \mathrm{Fe}^{2+}\right)$, and are used for diagnostic imaging and targeted therapeutic delivery. Lipid-magnetite complexes are incorporated on the liposome surface (134) or in the lipid bilayer or aqueous core (135) (Figure 9). Magnetic liposomes also act as a contrast agent in MRI imaging (136).

Preparation: Magnetic liposomes are prepared by a lipid hydration method. In this method, the lipid is dissolved in an organic solvent and dried to form a thin lipid film. A magnetizing agent is dissolved in water to form an aqueous magnetizing solution. The thin layer of lipid in the round bottom flask is hydrated with the aqueous magnetizing solution to form magnetic liposomes (137).

Applications: Magnetic liposomes provide "clickable" release of therapeutic agents by applying an alternating magnetic field. Magnetic liposomes provide permeability and controllable release (138-139). Magnetic liposomes are decorated with various surface ligands, such as polyethylene glycol, as targeting ligands (140), and are bi-functional which means they can carry fluorescent probe and MRI contrast agents for imaging as well as functional DNA delivery to the same cell (141). Recent research has reported super magnetic liposomes to treat cancer tissues and their metastasis without involving surgery or chemotherapeutic agents (142). When targeted super magnetic liposomes are subjected to an alternating magnetic field, they produce local hypothermia (about $45^{\circ} \mathrm{C}$ ) and cause tumor tissue necrosis (143).

\section{Niosomes:}

Niosomes are unilamellar or multilamellar vesicles composed of non-ionic surfactants (Figure 10). In niosomes, phospholipids bilayer is replaced by nonionic surfactants, making niosomes more stable and producing a longer shelf life. Niosomes can be administered through oral, intramuscular, intravenous and transdermal routes of administrations (144-147).

Preparation: Niosomes can be prepared by conventional lipid hydration and ether injection method with slight modifications depending on noisome application. Size homogeneity can be achieved by using an extrusion method (148-150).

Application: Niosome have been used for the treatment of leishmaniasis (151), cancer therapy $(152,153)$, immune induction (154) and as carrier for diagnostic agents (155). Research has been focused on providing controlled release of antimicrobial agents, anti-inflammatory drugs, peptides and various macromolecules (156-160). Cationic niosomes have been prepared by the combination of cationic lipids and non-ionic surfactants in niosomes (161). Recently, novel multicomponent drug delivery systems have been prepared in which preformed niosomes were loaded into liquid crystal gel. Both components of this system were prepared from the same mixture anionic and non-ionic surfactant for enhanced drug permeation after topical application (162).

\section{pH sensitive liposomes:}

In viral infections, mild acidic conditions are responsible for fusion of virus envelopes with cell membranes. This observation led to the development of $\mathrm{pH}$ sensitive liposomes which release loaded therapeutics at acidic $\mathrm{pH}$. Serum albumin and protein fragments have been reported to enhance liposome fusion at a lower $\mathrm{pH}$ of 6.5 (163-166). However, pH sensitive liposomes provide bioresponsive delivery to tissues. Lower $\mathrm{pH}$ values destabilize the lipid bilayer and drug is 
released at tumors, infections and inflammation (167-169). (Figure 9). Phosphatidylethanolamines and a stabilizing amphiphiles are used to stabilize liposomes at acidic pH (170-172). During endocytosis, the $\mathrm{pH}$ sensitive liposomes are exposed to the acidic environment of endosomes and may release their content inside the cells.

Preparation: Freeze thawing and reverse phase evaporation methods are used for the preparation of $\mathrm{pH}$ sensitive liposomes. Lipids, co-lipids and PEGare dissolved in an organic solvent. In freeze thawing, the lipid suspension is frozen followed by thawing in a water bath. After ten freeze-thawing cycles, $\mathrm{pH}$ sensitive liposomes are formed (173). In the Reverse Phase Evaporation method, a lipid film is hydrated with another organic solvent followed by adding an aqueous saline solution of therapeutics. The emulsion is vortexed and the organic solvent is evaporated to form $\mathrm{pH}$ sensitive liposomes (174).

Applications: $\mathrm{pH}$ sensitive fusogenic polymers have been subject of extensive research for the development of $\mathrm{pH}$ sensitive liposomes $(175,176)$. Hydrophobic derivatives of natural polymers have been conjugated with phospholipids molecules. Such liposomes demonstrate excellent $\mathrm{pH}$ responsiveness in vitro and in vivo $(177,178)$. Recent advancements have led to the development of 'fliposomes' which are more stable and show
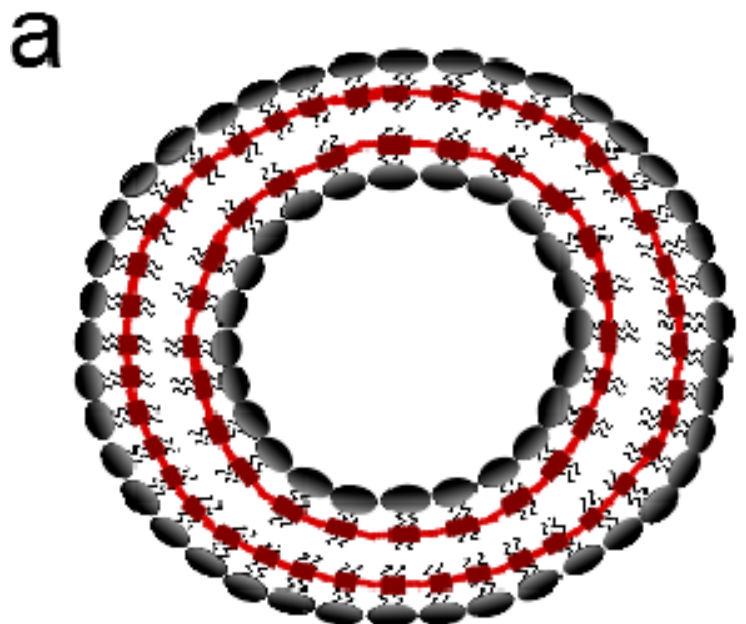

Figure 7: (a) A representation of polymerization of lipid molecules in liposome bilayer to increase the mechanical strength of lipid bilayer, (b) Capsosomes (not a liposome type), a polymer capsule containing numerous liposomes. 
Preparation: Polymerized liposomes are prepared by film hydration method. Cholesterol is chemically combined with polymerizable monomer. Phospholipids and the monomeric cholesterol are mixed in chloroform and dried in a rotary evaporator to form a thin film. The lipid film is hydrated with an aqueous buffer and sonicated for 30 minutes resulting in liposome formation. Polymerization of the lipid bilayer may be carried out by thermal, radiation or redox reaction. In thermal polymerization, the liposomes are heated to $60-70^{\circ} \mathrm{C}$ in the presence of free radical donor such as Azobis-isobutyronitde which initiates a polymerization reaction (190). In the radiation polymerization, liposomes are subjected to ultra violet (UV) radiations for 1-2 hours resulting in lipid polymerization (187). In the redox polymerization, redox initiator system consisting of ammonium per-sulphate and sodium meta-bisulphite are added to liposome formulations and heated in the presence of $\mathrm{N}_{2}$ to initiate polymerization. Residual polymeric monomers, reactants and un-entrapped drug are removed by dialysis (191).

Applications: Polymerized liposomes can be used for parenteral, oral and mucosal delivery of various diagnostic (191-193) and therapeutic agents. These are employed as vaccines and for the delivery of allergens, carbohydrates and antimicrobial agents (194-196). Polymerized liposomes are prepared in nanometer size range with multifunctional variants for controllable release responsive to $\mathrm{pH}$ and magnetic fields (197-200). In a recent study, liposomes were functionalized with surface adsorption of chitosan followed by polymerization of lipid bilayer.
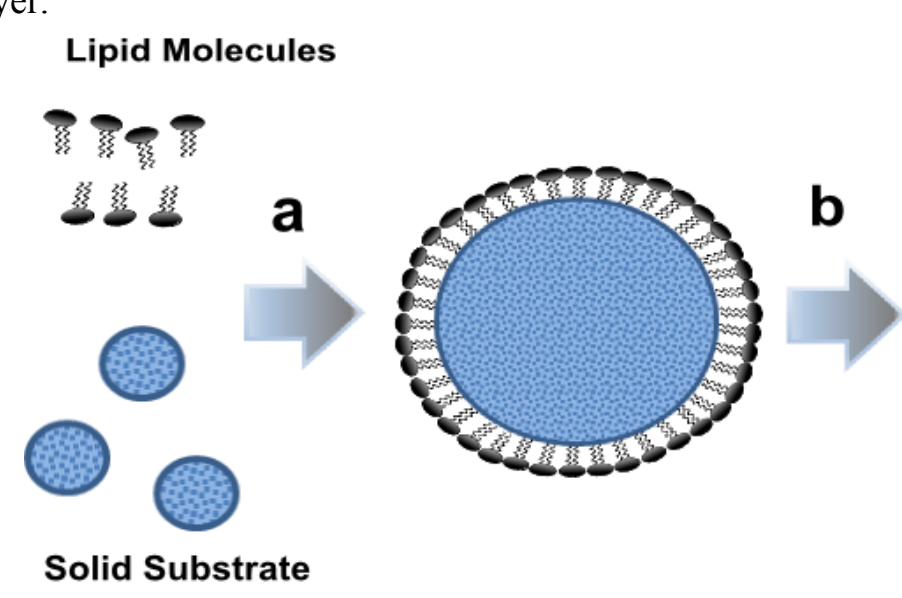

Figure 8: Synthesis of proliposomes. (a) A lipid is mixed with a solid substrate which forms lipid coated solid particles. (b) Upon hydration, solid substrate is dissolved and lipids arrange to form liposomes.

\section{Proliposomes:}

Proliposomes are dry and free flowing particles consisting of phospholipids coatings on water soluble powder particles. These lipid particles yield homogenous suspension of liposomes when dissolved in an aqueous solution. Proliposomes solve the problem associated with sterilization of liposomes as they have a high storage stability and provide simple large-scale production (201-203). Recently, liquid proliposomes have been reported that spontaneously form liposomes upon hydration (204) (Sun et al., 2013).

Preparation: Proliposomes are prepared by film deposition on the carrier method (Figure 8). Dried powder is placed in a round bottom flask and maintained at $30-40^{\circ} \mathrm{C}$. Drug and phospholipids are dissolved in an organic solvent. This organic solution is added in aliquots to a continuously rotating bed of dry powder. Complete drying of organic solvent occurs for each aliquot addition. The resulting proliposomes can be lyophilized or desiccated overnight to yield a fine free flowing powder (205). Proliposomes can also be prepared by fluid bed coating, spray drying and freezethawing depending upon the type of drug and its application (206).

Liquid proliposomes were prepared by dissolving hydrophobic drug, phospholipid, sodium deoxycholate, poloxamer and polyethylene glycol in ethanol. This light yellowish liquid was filled in hard gelatin capsule and dried. These liquid proliposomes will yield liposomes when manually mixed with distilled water (204). 
Applications: The administration of dry proliposomes via inhalation provide enhanced bioavailability and sustained therapeutic effects $(207,208)$. Proliposomes are reconstituted into a prescribed solvent to yield a liposome system. Effervescent proliposomes provide carbon dioxide upon dissolution (209). Proliposomes show great flexibility in the route of administration including reconstituted parenteral, oral, topical, intranasal administration and as dry powder aerosol (210). Proliposomes have successfully been used for enhancing bioavailability of anticancer drugs and other therapeutic agents (211-213).

\section{Temperature sensitive liposomes:}

Temperature sensitive lipids are stable at body temperature and undergo phase transition from gel to liquid at higher temperatures and provide a successful mean for targeted delivery (214). Temperature sensitive liposomes circulate throughout the body but when they reach an area of significant hyperthermia, they release therapeutics due to increased fluidity of the lipid bilayer (Figure 9).

Preparation: Temperature sensitive liposomes are prepared with slight modifications of the reverse phase evaporation and lipid hydration method. In both methods, temperature sensitive lipids are mixed in an organic solvent followed by evaporation of the solvent in a rotary evaporator. In the hand shake method, the lipid film is hydrated with an aqueous solution containing a therapeutic agent and a surfactants. The system is heated above their phase transition temperature to yield temperature sensitive liposomes (215). In the reverse evaporation method, the lipid film is redissolved in an organic solvent followed by the addition of an aqueous saline solution containing the therapeutic moiety. The mixture is heated to $60^{\circ} \mathrm{C}$ and vortexed for 30 seconds. The organic solvent is removed by rotary evaporation to yield temperature sensitive liposomes (216).
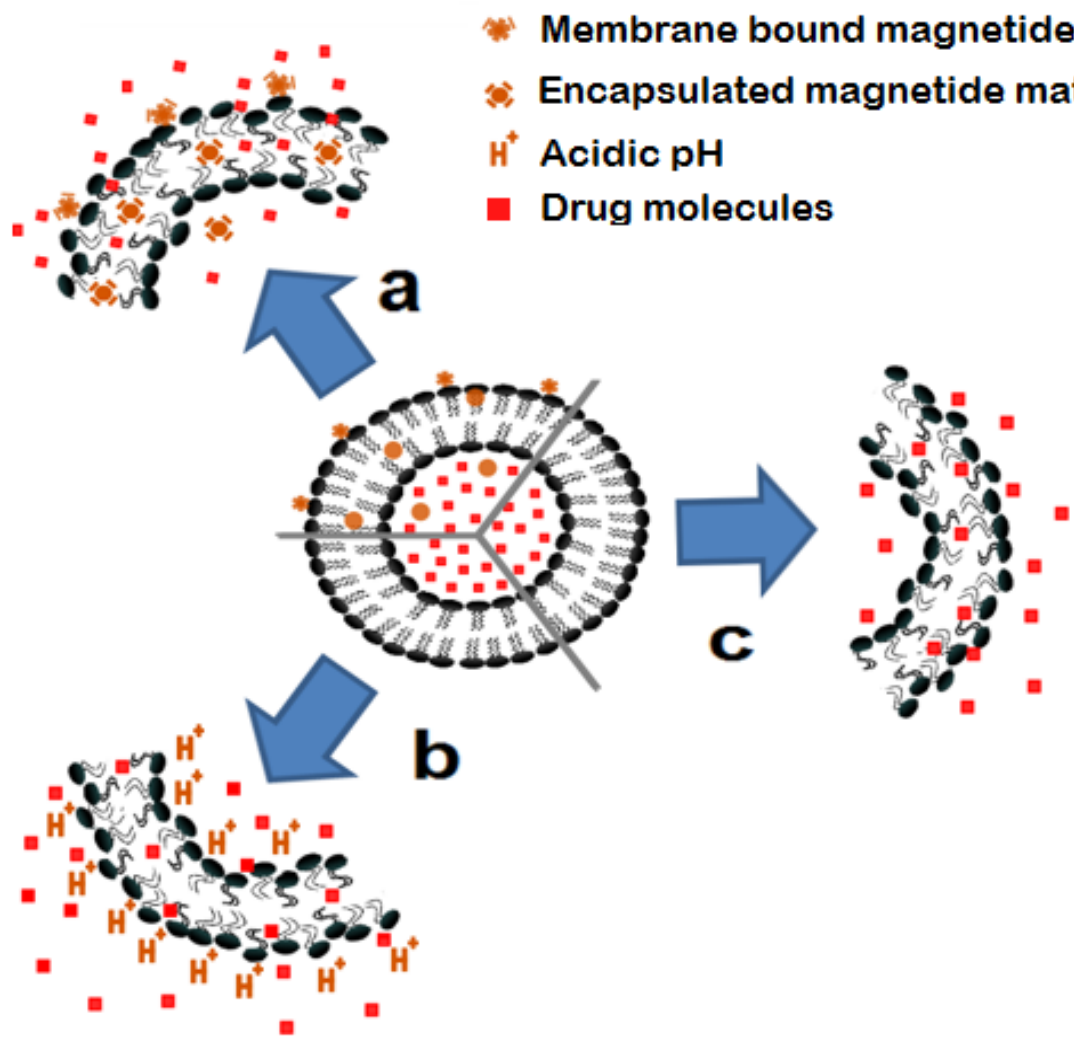

Figure 9. A representation of clickable drug release from magnetic, $\mathrm{pH}$ sensitive and temperature sensitive liposomes. (a) Magnetite materials (MRI contrast agents) are loaded in the bilayer and core, or attached to the lipid molecules. Under an externally applied alternating magnetic field, liposomes become leaky and release the loaded drug. (b) pH sensitive liposomes contains $\mathrm{pH}$ sensitive lipids in their bilayer which lose their geometric conformation at acidic $\mathrm{pH}$ and release the drug. (c) Temperature sensitive liposomes are activated by local or artificially applied hyperthermia and drug release is achieved. 
Applications: Traditional temperature sensitive liposomes (TTSL) have been used to target tumor cells as a result of relatively high temperature compared to normal body tissues $(217,218)$. TTSLs require a temperature of $42^{\circ} \mathrm{C}$ to $45^{\circ} \mathrm{C}$ for effective therapeutic release, which is impossible in In-vivo conditions normally. This problem has been solved by the development of low temperature sensitive liposomes (LTSL) which are stable at $37^{\circ} \mathrm{C}$ and show complete release of therapeutics at $39^{\circ} \mathrm{C}$ $(219,220)$. Another attempt is the development of new temperature sensitive liposomes (NTSL) (221) to control the release of therapeutic agents maintaining mild external hyperthermia generated by focused ultrasound (222), radiofrequency waves (223) and alternating magnetic field $(224,225)$. Recently, two steps hyperthermia has been reported to enhance antitumor activity of the encapsulated drugs. First hyperthermia $\left(41^{\circ} \mathrm{C}\right)$ induced hyperpermeable tumor vasculature which persisted for 8 hours while second hyperthermia $\left(42^{\circ} \mathrm{C}\right.$ or above) induced drug release from temperature sensitive liposomes (226).

\section{Transferosomes:}

These are ultra-deformable and stable advance liposomes which can cross the pores of the stratum corneum. The degree of deformability of transferosomes is directly related to their bioavailability. Transferosomes are prepared from different ratios of phosphatidylcholine and surfactants. Surfactants act as edge-activators and incorporate deformability into transferosomes (Figure 10). By changing the type and ratio of surfactant, one can optimize the vesicle morphology, size and therapeutic loading $(227,228)$. The addition of permeation enhancers into transferosomes further improves therapeutic delivery through the skin (229).

Preparation: Transferosomes are prepared by a film hydration method. Lipids and surfactants are dissolved in an organic solvent. The organic solvent is evaporated using a rotary evaporator to form a lipid film. This film is hydrated with an aqueous buffer and sonicated for 5 minutes to obtain transferosomes (230).

Applications: Transferosomes have been used to deliver macromolecules which are difficult to be transported by other dosage forms. Transulin is transferosomal insulin complex which shows in vivo delivery similar to subcutaneous insulin and lacks the problem associated with non-compliance of injections (231). Recent research has shown that corticosteroids might be ideal candidate for transferosomal delivery (232-234).

Different types of next generation liposomes or their combination present exciting solutions for diagnostic as well as therapeutic applications. Table 2 summarizes challenging disease conditions that have been broadly investigated with liposomes based therapy.

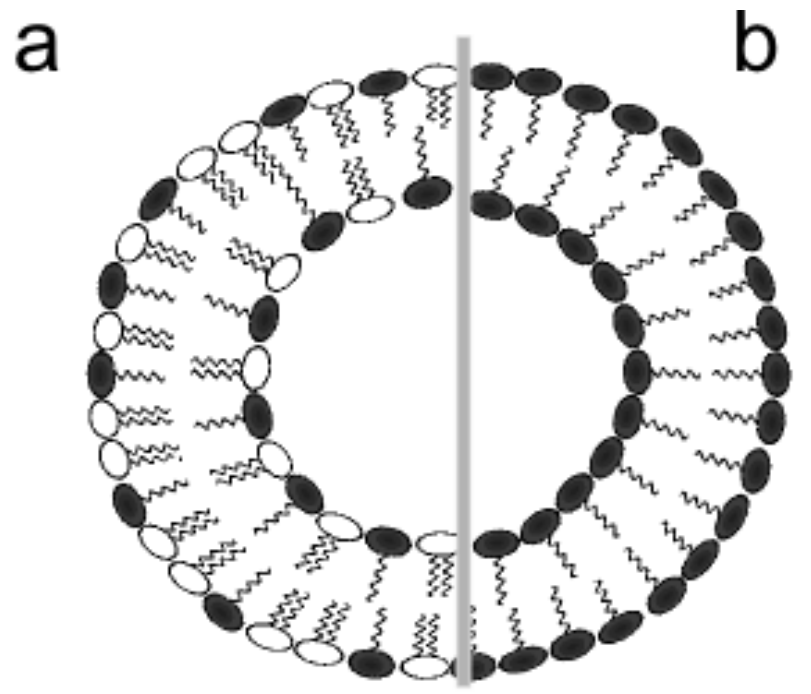

\$ Surfactant Molecule

Lipid Molecule

Figure 10. (a) Represents transferosomes formed by mixing surfactants and lipids (b) represents Niosomes containing bilayer of surfactant molecules only. 
Table 2. Clinical diseases and the liposomes drug delivery

\begin{tabular}{|c|c|c|}
\hline Therapeutic Application & Type of liposome & Novelty in Drug Delivery \\
\hline \multirow[t]{7}{*}{ Cancer Chemotherapy } & Cochelates & $\begin{array}{l}\text { Cation-stabilized liposomes prolong circulation time of } \\
\text { anticancer drugs }\end{array}$ \\
\hline & Niosomes & $\begin{array}{l}\text { Improve stability of encapsulated anticancer drug and } \\
\text { final product due to bilayer of stable non-ionic } \\
\text { surfactants }\end{array}$ \\
\hline & pHsensitive liposome & Release of drugs at tumor sites in acidic enviorments. \\
\hline & Polymerized Liposomes & Polymerization of lipid bilayer \\
\hline & $\begin{array}{l}\text { Temperature sensitive } \\
\text { liposomes }\end{array}$ & $\begin{array}{l}\text { Lipid bilayer destabilizes at elevated temperature of } \\
\text { tumors }\end{array}$ \\
\hline & Immunoliposomes & $\begin{array}{l}\text { Tumor targeted delivery of chemotherapeutic agents via } \\
\text { ligends }\end{array}$ \\
\hline & Magnetic Liposomes & $\begin{array}{l}\text { Drug loaded magnetic liposomes can be localized by } \\
\text { external magnetic field to provide clickable drug release }\end{array}$ \\
\hline \multirow[t]{7}{*}{ Vaccine } & Archeosome & $\begin{array}{l}\text { Archaeal bacteria contains ether lipids which are stable } \\
\text { and act as self-adjuvants for vaccines }\end{array}$ \\
\hline & Cocheltaes & $\begin{array}{l}\text { Cations stabilized liposomes provide long circulation } \\
\text { time and used to encapsulated protein antigens }\end{array}$ \\
\hline & ISCOMs & Quillaja Saponins act as self-adjuvant for vaccines \\
\hline & Polymerized Liposome & Polymerization of lipid bilayer \\
\hline & Transferosomes & $\begin{array}{l}\text { Increased penetration of vaccines in transcutaneous } \\
\text { immunization }\end{array}$ \\
\hline & $\begin{array}{l}\text { Immunosomes } \\
\text { Virosomes }\end{array}$ & $\begin{array}{l}\text { Virus antigens on the surface provide adjuvant property } \\
\text { and help in adapting virus like entrance into cells }\end{array}$ \\
\hline & Exosomes & $\begin{array}{l}\text { Their free movement in tumor microenvironment } \\
\text { provides efficient delivery of anticancer drugs and } \\
\text { vaccines to cancer cells. }\end{array}$ \\
\hline Gene Therapy & Lipoplexes & $\begin{array}{l}\text { Bilayer of positively charged lipids encapsulate and } \\
\text { binds negative charged DNA on its surface }\end{array}$ \\
\hline
\end{tabular}

Exosomes

Intrinsic ability to cross biological barriers and enter cells effective delivery of DNA through transfection

Antimicrobials

\section{Sensitive macromolecules}

Niosomes

Polymerized Liposome

Ethosomes

and Polymerized Liposome

Gas containing liposomes

Proliposomes

Cubosomes
Improved the stability of encapsulated antimicrobial drugs and final product due to stable bilayer of nonionic surfactants

Polymerization of the lipid bilayer protects the encapsulated drugs from degradation

Anti-inflammatory and antifungal drugs for skin and deep tissuesdelivery.

Polymerization of the lipid bilayer protects sensitive molecules from degradation

Encapsulate novel therapeutic gasses

Sensitive molecules are stored in dry state to improve stability and withstand storage conditions

More resistant to degrading factors and provide oral, parenteral, ocular and topical delivery of sensitive molecules 
Topical drug delivery Transferosomes

Ethosomes

Diagnostic Techniques

Magnetic liposomes

Immunoliposomes

Gas containing liposomes
Surfactants in lipid bilayer provide flexibility and improve penetration through skin. Increased skin penetration of insulin and used for transcutaneous immunization.

Transcutaneous immunization and topical delivery of anti-inflammatory drugs

Paramagnetic agents loaded on liposomes act as contrast agent for MRI

Ligands such monoclonal antibodies are attached to liposome surface to target cancerous tissues expressing tumor specific receptors. This confines chemotherapeutics release to tumor tissues. Contain gas bubbles that echo ultrasound waves

\section{CONCLUSION}

Liposomes have emerged as one of the most studied novel drug delivery system in the last two decades. Liposomes have revolutionized medical research for cancer chemotherapy, gene therapy, vaccines, antimicrobial and diagnostic agents. The US FDA has approved thirteen liposome formulations for clinical use and many other have been tested in clinical trials. Highly potent chemotherapeutic agents encapsulated in stealth liposomes offer long circulation time. Immunoliposomes with various targeting ligands deliver the payload specifically to target tissues and safeguard other normal tissues from toxic effects. Liposome encapsulated drugs have shown much high efficacy as compared to other conventional drug delivery systems. The main advantage of modern liposomes lies in their sustained action, enhanced bioavailability, high cellular uptake and targeted delivery of therapeutic agents. However, industrial scale up of sophisticated laboratory preparation methods is still a challenge to be addressed.

Keywords: liposomes, cancer treatment, drug targeting, micelle systems, drug delivery, clinical applications.

\section{REFERENCES:}

1. Bangham, A. D., Horne, R.W. Negative staining of phospholipids and their structural modification by surface active agents as observed in the electron microscope. J Mol Biol, 1964; 8: 660668 .
2. Heap B, Gregoriadis G. Alec Douglas Bangham. 10 November 1921 —9 March 2010. Biogr Mems Fell R Soc, 2011; 57:25-43.

3. Gregoriadis G, Leathwood PD, Ryman BE. Enzyme entrapment in liposomes. FEBS Lett, 1971; 14:95-99.

4. Rahman YE, Rosenthal MW, Cerny EA, Moretti ES. Preparation and prolonged tissue retention of liposome encapsulated chelating agents. J Lab Clin Med, 1974; 83:640-647.

5. Chaize B, Colletier JP, Winterhalter M, Fournier D. Encapsulation of enzymes in liposomes: high encapsulation efficiency and control of substrate permeability. Artif Cells Blood Substit Immobil Biotechnol, 2004; 32:67-75.

6. Rooijen N, Nieuwmegen R. Liposomes in immunology: multilamellar phosphatidylcholine liposome as a simple biodegradable and harmless adjuvant without any immunogenic activity of its own. Immunol commun, 1980; 9:243-256.

7. Dai Y, Zhou R, Liu L, Lu Y, Qi J, Wu W. Liposomes containing bile salts as novel ocular delivery systems for tacrolimus (FK506): in vitro characterization and improved corneal permeation. Int J Nanomedicine, 2013; 8:1921-33.

8. Yang Q, Ma Y, Zhao Y, She Z, Wang L, Li J, Wang C, Deng Y. Accelerated drug release and clearance of PEGylated epirubicin liposomes following repeated injections: a new challenge for sequential low-dose chemotherapy. Int $\mathrm{J}$ Nanomedicine, 2013; 8:1257-1268.

9. Drummond DC, Meyer O, Hong K. Optimizing liposomes for delivery of chemotherapeutic agents to solid tumors. Pharmacol Rev, 1999; 51;691743.

10. Gill SE, Savage K, Wysham WZ, Blackhurst DW, Winter WE, Puls LE. Continuing routine cardiac surveillance in long-term use of pegylated liposomal doxorubicin: Is it necessary? Gynecol Oncol, 2013; 129(3): 544-47. 
11. Hatakeyama H, Akita H, Harashima H. The Polyethyleneglycol Dilemma: Advantage and Disadvantage of PEGylation of Liposomes for Systemic Genes and Nucleic Acids Delivery to Tumors. Biol Pharm Bull, 2013; 36(6): 892-899.

12. Gabizon A, Papahadjopoulos D.The role of surface charge and hydrophilic groups on liposome clearance in vivo. Biochim Biophys Acta, 1992; 1103:94-100.

13. Ahmad I, Allen TM. Antibody-mediated specific binding and cytotoxicity of liposome-entrapped doxorubicin to lung cancer cells in vitro.Cancer Res, 1992; 52:4817-4820.

14. Kye-Il J, Liang X, Shhuanglong L, Yarong L, ChiLin L, Peter SC, Michael KW, Zibo L, Pin W. Crosslinked multilamellar liposomes for controlled delivery of anticancer drugs. Biomaterials, 2013; 34:3098-3109.

15. Jack S, Zhu FZ. Uniform-sized, multi-drug carrying and photosensitive liposomes for advance drug delivery. Patent Cooperation Treaty (PCT), WO 2009091531 A2, 2009.

16. Seo S, Lee J, Choi EJ, Kim EJ, Song JY, Kim J. Polydiacetylene Liposome Microarray Toward Influenza A Virus Detection: Effect of Target Size on Turn-On Signaling. Macromol Rapid Comm, 2013; 34(9):743-748.

17. Pippa N, Pispas S, Demetzos C. The imaging and the fractal metrology of chimeric liposomal Drug Delivery nano Systems: the role of macromolecular architecture of polymeric guest. J Liposome Res, doi:10.3109/08982104.2014.891232.

18. Fugit KD, Anderson BD. The role of $\mathrm{pH}$ and ringopening hydrolysis kinetics on liposomal release of topotecan. J Control Rel, 2014; 174: 88-97.

19. Li C, Tian M. Radiolabeled Liposomes as Drug Delivery Nanotheranostics. Drug Delivery Applications of Noninvasive Imaging: Validation from Biodistribution to Sites of Action. 2013, John Wiley \& Sons, Inc.

20. Cern A, Barenholz Y, Tropsha A, Goldblum A. Computer-aided design of liposomal drugs: In silico prediction and experimental validation of drug candidates for liposomal remote loading. J Control Rel, 2014; 173: 125-131.

21. Chang HI, Cheng MY, Yeh MK. ClinicallyProven Liposome-Based Drug Delivery: Formulation, Characterization and Therapeutic Efficacy. Sci Rep, 2012; 1:2-8.

22. Rodriguez MA, Pytlik R, Kozak T, Chhanabhai M, Gascoyne R, Lu B, Deitcher SR, Winter JN. Vincristine sulfate liposomes injection (Marqibo) inheavily pretreated patients with refractory aggressive non-Hodgkin lymphoma: report of the pivotal phase 2 study. Cancer, 2009; 115:34753482 .
23. Madni AU, Ahmad M, Akhtar N, Usman M. New Simultaneous High Performance Liquid Chromatographic Method for Determination of NSAIDs and Opioid Analgesics in Advanced Drug Delivery Systems and Human Plasma. World Academy of Science, Engineering and Technology (WASET), 2009; 55:158-163.

24. Riaz M. Liposomes preparation methods. Pak J Pharm Sci, 1996; 19:65-77.

25. Sprott GD, Dicaire CJ, Fleming LP, Patel GB. Stability of liposomes prepared from archaeobacterial lipids and phosphatidylcholine mixtures. Cell Matt, 1996; 6:143-155.

26. Krishnan L, Sprott GD. Archaeosome adjuvants: immunological capabilities and mechanism(s) of action. Vaccine, 2008, 26:2043-55.

27. Benvegnu $T$, Lemiegre, Cammas MS. New generation of liposomes called archeosomes based on natural or synthetic archael lipids as innovative formulations for drugdelivery. RecentPatDrugDeliv Formul, 2009; 3:206-220.

28. Applications of Extremophilic Archaeal Lipids in the Field of Nanocarriers for Oral/Topical Drug Delivery. Benvegnu, Thierry; Lemiegre, Loic; Dalencon, Sylvain; Jeftic, Jelena. Current Biotechnology, Volume 2, Number 4, November 2013, pp. 294-303(10)

29. Sprott GD, Choquet C, Patel GB, Irena E. Formation of stable liposomes from lipid extracts of archaebacteria (archaea).Patent Cooperation Treaty (PCT), WO9308202,1993.

30. Julie B, Sandrine CM, Pierrick A, Thierry B. Preparation and Characterization of Stealth Archaeosomes Based on a Synthetic PEGylated Archaeal Tetraether Lipid. J Drug Deliv, 2011; 2011:396068.

31. Krishnan L, Sad S, Patel GB, Sprott GD. Archaeosomes induce long-term CD8+ cytotoxic $\mathrm{T}$ cell response to entrapped soluble protein by the exogenous cytosolic pathway, in the absence of CD4+ T cell help. J Immunol, 2000; 165:5177-85.

32. Krishnan L, Dicaire CJ, Patel GB, Sprott GD. Archaeosome vaccine adjuvants induce strong humoral, cell mediated, and memory responses: comparison to conventional liposomes and alum. Infect Immun, 2000; 68:54-63.

33. Conlan JW, Krishnan L, Willick GE, Patel GB, Sprott GD. Immunization of mice with lipopeptide antigens encapsulated in novel liposomes prepared from the polar lipids of various Archaeobacteria elicits rapid and prolonged specific protective immunity against infection with the facultative intracellular pathogen, Listeria monocytogenes. Vaccine, 2011; 19:3509-3517.

34. Benvegnu T, Plusquellec D, G. Réthoré, M. Sachet, C. Ferec, T. Montier, P. Delépine, P. Lehn, Compounds analogous to membrane lipids 
in archaebacteria and liposomal compositions including said compounds. Patent Cooperation Treaty (PCT), WO2006061396, 2006.

35. Réthoré G, Montier T, Le Gall T. Archaeosomes based on synthetic tetraether-like lipids as novel versatile gene delivery systems. Chem Comm, 2007; 20:2054-2056. T.

36. Mannino RJ, Gould-Fogerite S, Krause-Elsmore SL, Delmarre D, Lu R. Novel encochleation methods, cochleates and methods of use. U.S. Patent, 2005/0013854, 2005.

37. Tuo J. Cochleates without metal cations as the bridging agents. WIPO Patent Application, WO/2004/012709, 2003.

38. Ruying L,Raphael JM. Amphiphilic nucleotide cochleate compositions and methods of using the same. USPTO Applicaton, 20120232260, 2008.

39. Zarif L, Jin T, Segarra I, Mannino RJ. Hydrogelisolated cochleate formulations, process of preparation and their use for the delivery of biologically relevant molecules. U.S. Patent, 6592894, 2003.

40. Gould-Fogerite S, Kheiri MT, Zhang F. Targeting immune response induction with cochleate and liposome based vaccines. Adv Drug Del Rev, 1998; 32:273-287.

41. Zarif L, Graybill J, Perlin D, Mannino RJ. Cochleates: new lipid based drug delivery system. J Liposome Res, 2000; 10:523-538.

42. Amram M, Richards ME, Raquel FE, Brigitte PS.Antibiotic drug delivery and potentiation. U.S. Patents, US 20120237562, 2012.

43. Ma Y, Wang Z, Zhao W, Lu T, Wang R, Mei Q, Chen T. Enhanced bactericidal potency of nanoliposomes by modification of the fusion activity between liposomes and bacterium. Int $\mathrm{J}$ Nanomedicine, 2013; 8: 2351-2360.

44. Garg G, Saraf S. Cubosomes: an overview. Biol Pharm Bull 2007; 30:350-3.

45. Rizwan SB, Dong YD, Boyd BJ, Rades T, Hook S.Characterization of bicontinuous cubic liquid crystalline systems of phytantriol and water using cryo field emission scanning electron microscopy (cryo FESEM). Micron, 2007; 38:478-485.

46. Wu HB, Huo DF, Jiang XG. Advances in the study of lipid-based cubic liquid crystalline nanoparticles as drug delivery system. Acta Pharm Sinica, 2008; 43:450-5.

47. Angelov B, Angelova A, Garamus VM, Drechsler M, Willumeit R, Mutafchieva R, Stěpánek P, Lesieur S.Earliest stage of the tetrahedral nano channel formation in cubosome particles from unilamellar nano vesicles.Langmuir, 2012; 28:16647-55.

48. Di B, Tao Z, James BM, Bi-Botti CY. Formulation of Dacarbazine-loaded Cubosomes.
Part III. Physicochemical Characterization. AAPSPharmSciTech, 2010; 11:1243-1249.

49. Rizwan SB, Assmus D, Boehnke A, Hanley T, Boyd BJ, Rades T, Hook S. Preparation of phytantriol cubosomes by solvent precursor dilution for the delivery of protein vaccines. Eur $\mathbf{J}$ Pharm and Biopharm, 2011; 79:15-22.

50. Rattanapak T, Young K, Rades T, Hook S. Comparative study of liposomes, transfersomes, ethosomes and cubosomes for transcutaneous immunization: characterization and in vitro skin penetration. J Pharm Pharmacol, 2012; 64:15601569.

51. Yang Z, Tan Y, Chen M, Dian L, Shan Z, Peng X, Wu C.Development of Amphotericin B-Loaded Cubosomes Through the SolEmuls Technology for Enhancing the Oral Bioavailability. AAPS PharmSciTech, 2012; 13:1483-91.

52. Wu H, Li J, Zhang Q, Yan Z, Guo L, Gao X, Qiu M, Jiang X, Lai R, Chen H.A novel small Odorranalectin-bearing cubosomes: preparation, brain delivery and pharmacodynamic study on amyloid- $\beta_{25-35}$-treated rats following intranasal administration. Eur J Pharm and Biopharm, 2012; 80:368-78.

53. Fraser SJ, Mulet $X$, Martin L, Praporski S, Mechler A, Hartley PG, Polyzos A, Separovic F.Surface immobilization of bio-functionalized cubosomes: sensing of proteins by quartz crystal microbalance. Langmuir, 2012; 28:620-7.

54. Hinton TM, Grusche F, Acharya D, Shukla R, Bansal V, Waddington LJ, Monaghan P, Muir BW. Bicontinuous cubic phase nanoparticle lipid chemistry affects toxicity in cultured cells. Toxicol Res, 2014; 3:11-22.

55. Fan Chao, Li X, Zhou Y, Zhao Y, Ma S, Li W, Liu Y, Li G. Enhanced Topical Delivery of Tetrandrine by Ethosomes for Treatment of Arthritis. Biomed Res Int, 2013; 2013:161943.

56. Xiao-Jing X, Lang Y, Yi Y, Bai-Yu Z, Qiu-He S, Jun D, Fei H.Study of the biological function and penetration pathways of the mouse epidermal growth factor ethosomal delivery system.Exp Dermatol,2011; 20:943-958.

57. Touitou E. Composition of applying active substance to or through the skin. US patents, US 5540934, 1996.

58. Touitou E. Drug delivery across the skin. Exp Opinion Biol Ther, 2002; 2002:723-733.

59. Verma DD, Fahr A. Synergistic penetration effect of ethanol and phospholipids on the topical delivery of Cyclosporin A. J Control Release, 2004; 97:55-66. 
60. Poonam V, Pathak K. Therapeutic and cosmeceutical potential of ethosomes: An overview.J AdvPharm Tech Res, 2010; 1:274-282.

61. Mishra D, Mishra PK, Dubey V, Nahar M, Jain NK. Systemic and mucosal immune response induced by transcutaneous immunization using Hepatitis B surface antigen-loaded modified liposomes. J Control Rel, 2007; 33:424-33.

62. Anitha $\mathrm{P}$, Ramkanth S, Uma-Sankari $\mathrm{K}$, Alagusundaram M, Gnanapraksah K, Devaki DP, Indira PR. Ethosomes - A noninvasive vesicular carrier for transdermal drug delivery. Int $\mathrm{J}$ Rev Life Sci, 2011; 1:17-24.

63. Touitou E, Godin B, Dayan N. Intracellular delivery mediated by ethosomal carrier. Biomater, 2001; 22:3055-9

64. Topical ethosomal capsaicin attenuates edema and nociception in arthritic rats. Sarwa KK, Rudrapal M, Mazumder B. doi:10.3109/10717544.2013.861041.

65. Paolino D, Lucania G, Mardente D, Alhaique F, Fresta M. Ethosomes for skin delivery of ammonium glycyrrhizinate: In vitro percutaneous permeation through human skin and in vivo antiinflammatory activity on human volunteers. J Control Release, 2005; 106:99-110.

66. Dubey V, Mishra D, Dutta T, Nahar M, Saraf DK, Jain NK. Dermal and transdermal delivery of an anti-psoriatic agent via ethanolic liposomes. J Control Release, 2007; 123:148-54.

67. Godin B, Touitou E. Erythromycin ethosomal systems: Physicochemical characterization and enhanced antibacterial activity. Curr Drug Deliv, 2005; 2:269-75.

68. Teerawan R. Comparative study of liposomes, transfersomes, ethosomes and cubosomes for transcutaneous immunization: characterization and in vitro skin penetration. J Pharm Pharmacol, 2012; 64:1560-1569.

69. El Maghraby GM, Williams AC.Vesicular systems for delivering conventional small organic molecules and larger macromolecules to and through human skin. Expet Opin Drug Deliv, 2009; 6:149-63.

70. Rita C, Laura R, Enea M, Drechsler M, Elisabetta E. Colloidal Dispersions for the Delivery of Acyclovir: A Comparative Study. Indian J Pharm Sci, 2011; 73:687-693.

71. Zhang JP, Wei YH, Zhou Y, Li YQ, Wu XA.Ethosomes, binary ethosomes and transfersomes of terbinafine hydrochloride: a comparative study. Archives Pharm Res, 2012; 35:109-17.

72. Park JE, Tan HS, Datta A, Lai RC, Zhang H, Meng W, Lim SK, Sze SK. Hypoxic Tumor Cell Modulates Its Microenvironment to Enhance Angiogenic and Metastatic Potential by Secretion of Proteins and Exosomes. Mol Cell Proteomics, 2010; 9:1085-99.

73. Sander AAK, Pieter V, Susan MD, Wouter WS, Raymond MS. Exosomemimetics: a novel class of drug delivery systems. Int J Nanomedicine, 2012; 7:1525-1541.

74. Hong T, Min H, Li-Xing Y, Yue JL, Xia G, WenJing Z, Rui-Zhen J. Suppression of inflammation by tumor-derived exosomes: a kind of natural liposome packaged with multifunctional proteins. J Liposome Res, 2012; 22:346-52.

75. Johnsen KB, Gudbergsson JM, Skov MN, Pilgaard L, Moos T, Duroux M. A comprehensive overview of exosomes as drug delivery vehicles - Endogenous nanocarriers for targeted cancer therapy. Bioch Biophys Acta Rev Cancer, 2014; 1846:75-87.

76. Ruenn CL, Ronne WYY, Kok HT, Sai KL. Exosomes for drug delivery-a novel application for the mesenchymal stem cell. Biotechnology Advances, 2012; 31:543-51.

77. Karine L, Claude M, Safouane H, Sébastien $\mathrm{R}$, Jean-François FP, Toshihide K, Jean-Pierre S, Bertrand P, Christian B, Michel R. Mast cell- and dendritic cell-derived exosomes display a specific lipid composition and an unusual membrane organization. Biochem J, 2004; 380:161-71.

78. Aaron T, Hug DLP, Alexander M S . The application of exosomes as a nanoscale cancer vaccine. Int J Nanomedicine, 2010; 5:889-900.

79. Lakhal S, Wood MJ. Exosome nanotechnology: an emerging paradigm shift in drug delivery: exploitation of exosomes nanovesicles for systemic in vivo delivery of RNAi heralds new horizons for drug delivery across biological barriers. BioEssays, 2011; 33:737-41.

80. Liu R, Wei X, Yao Y, Chai Q, Chen Y, Xu Y.The preparation and characterization of gas bubble containing liposomes.Conference Proceedings: IEEE Engineering in Medicine and Biology Soceity, 2005; 4:3998-4001.

81. Geers, B., De Wever, O., Demeester, J., Bracke, M., De Smedt, S. C. and Lentacker, I. (2013), Targeted Liposome-Loaded Microbubbles for Cell-Specific Ultrasound-Triggered Drug Delivery. Small, 9: 4027-4035.

82. Min-Fan C, Ko-Jie C, Hsiang-Fa L, Zi-Xian L, Wei-Tso C, Xia Y, Hsing-Wen S.A Liposomal System Capable of Generating $\mathrm{CO}_{2}$ Bubbles to Induce Transient Cavitation, Lysosomal Rupturing, and Cell Necrosis. Angew Chem Int Ed, 2012; 51:10089-10093.

83. Kee PH, Kim H, Huang S, Laing ST, Moody MR, Vela D, Klegerman ME, McPherson DD. Nitric Oxide Pretreatment Enhances Atheroma Component Highlighting in Vivo with Intercellular Adhesion Molecule-1-Targeted 
Echogenic Liposomes. Ultrasound Med Biol, 2014; 40:1167-1176.

84. George LB, Hyunggun K, Patrick HK, Jaroslaw A, Christy K, McPherson D, Shao-Ling H. In Vivo Therapeutic Gas Delivery for Neuroprotection with Echogenic Liposomes. Circulation, 2010; 122:1578-87.

85. Bryne JD, Betancourt T, Brannon-Peppas L. Active targeting schemes for nanoparticle systems in cancer therapeutics. Adv Drug Del Rev, 2008; 60:1615-1626.

86. Huang A, Kennel SJ, Huang L. Interactions of immunoliposomes with target cells. J Biol Chem 1983; 258:14034-14040.

87. Sullivan SM, Connor J, Huang L. Immunoliposomes: preparation, properties, and applications. Med Res Rev, 1986; 6:171-195.

88. Chang EH, Pirollo KF. Simplified and improved method for preparing an antibody or an antibody fragment targeted immunoliposome for systemic administration of a therapeutic or diagnostic agent.U.S. Patents, US20100329981, 2010.

89. Vladimir P. Immunoliposomes and PEGylated Immunoliposomes: Possible Use for Targeted Delivery of Imaging Agents.Immuno Methods, 1994; 4:244-258.

90. Hood RR, Shao C, Omiatek DM, Vreeland WN, DeVoe DL. Microfluidic Synthesis of PEG- and Folate-Conjugated Liposomes for One-Step Formation of Targeted Stealth Nanocarriers. Pharm Res, 2013; 30:1597-1607.

91. Joshua G, Allen M, Deepak S, Linda AS, Raymond S, Steve PW. Anti-alpha V immunoliposome compositions, methods and uses. U.S. Patent, US 8138315, 2011.

92. Andreas W, Christoph R, Reto R, Annette O, Imke A, Richard H, Gerhard C, Christoph M.Targeting tumor-associated endothelial cells: anti-VEGFR2-immunoliposomes mediate tumorvessel disruption and inhibit tumor growth. Clin Cancer Res, 2012; 18:454-64.

93. Mamot C, Ritschard R, Wicki A, Küng W, Schuller J, Herrmann R, Rochlitz C. Immunoliposomal delivery of doxorubicin can overcome multidrug resistance mechanisms in EGFR-overexpressing tumor cells. J Drug Target, 2012; 20:422-32.

94. Barrajón-Catalán E, Menéndez-Gutiérrez MP, Alberto F, Miguel S, Angela C, Vicente M. A Multipurpose Strategy in Breast Cancer Targeted Therapy.Indian J Exp Biol, 1997; 15:840-4.

95. Muzykantov VR.Immunotargeting of catalase to the pulmonary vascular endothelium.Methods in Molec Med, 2000; 25:241-54.

96. Robert CS, Jenna MR, Zhanna I, Bin W, Lee-Gau CP, Andrew CI, Deborah LC, Mohammad FK. Targeting VEGF-encapsulated immunoliposomes to MI heart improves vascularity and cardiac function. FASEB J, 2009; 23:3361-7.

97. Katharina M, Ronny R, Sina F, Oliver S, Roland EK. Dual Targeting of Tumor Cells with Bispecific Single-Chain Fv-Immunoliposomes. Antibodies, 2012; 1:199-214.

98. Perrin P, Sureau P, Thibodeau L. Structural and immunogenic characteristics of rabies Immunosomes. Dev Biol Standardization, 1985; 60:483-91.

99. Koch M, Krieger ML, Stolting D, Brenner N, Beier M, Jaehde U, Wiese M, Rover HD, Bendas G. Overcoming chemotherapy resistance of ovarian cancer cells by liposomal cisplatin: Molecular mechanisms unveiled by gene expression profiling. Biochem Pharmacol, 2013; 85: 1077-1090.

100. Thibodeau L, Laval-des-Rapides Q, Armand B, Pierre N.Formation of an immunosome exclusively made of viral antigens reconstituted on an artificial membrane. German Patents, DE3173713, 1986.

101. Macauley MS, Pfrengle F, Rademacher C, Nycholat CM, Gale AJ, von Drygalski A, Paulson JC. Antigenic liposomes displaying CD22 ligands induce antigen-specific B cell apoptosis. J Clin Invest, 2013; 123(7):3074-3083.

102. Kwong B, Gai SA, Elkhader J, Wittrup KD, Irvine DJ. Localized Immunotherapy via LiposomeAnchored Anti-CD137 + IL-2 Prevents Lethal Toxicity and Elicits Local and Systemic Antitumor Immunity. Cancer Res, 2013; 73:154758.

103. Lise T. Immunosome technology to improve antigen presentation for efficient and safe viral vaccines Mol Eng, 1991; 1:275-293.

104. Cryz SJ, Que JU, Gluck R, A virosome vaccine antigen delivery system does not stimulate an antiphospholipid antibody response in humans, Vaccine 14 (1996) 1381-3.

105. Masoumeh TK, Abbas J, Shenagari M, Hamidreza H, Farzaneh S, Fatemeh A, Reza S.Influenza virosome/DNA vaccine complex as a new formulation to induce intra-subtypic protection against influenza virus challenge. Antiviral Res, 2012; 95:229-236.

106. H. Peter and G. S. Richard, Fusogenic Virosomes Prepared by Partitioning of Vesicular Stomatitis Virus G Protein Into Preformed Vesicle, J. Biol. Chem. 269 (1994) 4050-4056.

107. Lise T, CeLine T, Lise L. Oral Priming Followed by Parenteral Immunization with HIVImmunosomes Induce HIV-1-Specific Salivary and Circulatory IgA in Mice and Rabbits. AIDS Res Hum Retroviruses, 1992; 8:1379-1379.

108. Leb VM, Jahn-Schmid B, Kueng HJ, Schmetterer KG, Haiderer D, Neunkirchner A, Fischer DF, 
Hartl A, Thalhamer J, Steinberger P, Bohle B, Seed B, Pickl WF. Modulation of allergen-specific T-lymphocyte function by virus-like particles decorated with HLA class II molecules. J Allergy Clin Immunol, 2009; 124:121-128.

109. Simanouchi T, Yoshimoto N, Hiroiwa A, Nishiyama K, Hayashi K, Umakoshi H. Relationship between the mobility of phosphocholine headgroup and the proteinliposome interaction: A dielectric spectroscopic study. Coll Surf B, 2014; 16:343-350.

110. Shafique M, Meijerhof T, Wilschut J, de Haan A. Evaluation of an intranasal virosomal vaccine against respiratory syncytial virus in mice: effect of TLR2 and NOD2 ligands on induction of systemic and mucosal immune responses. PLoS One, 2013; 8:e61287.

111. Gluck R, Mischler R, Brantschen S. Immunopotentiating reconstituted influenza virus virosome vaccine delivery system for immunization against hepatitis A. J Clin Invest, 199290 (1992) 2491-5.

112. Kueng HJ, Leb VM, Haiderer D, Raposo G, Thery C, Derdak SV, Schmetterer KG, Neunkirchner A, Sillaber C, Seed B, Pickl WF. General strategy for decoration of enveloped viruses with functionally active lipid-modified cytokines. J Virol, 2007; 81:8666-8676.

113. Kersten GFA, Crommelin DJA. Liposomes and ISCOMs. Vaccine, 2003; 21:915-920.

114. Pham HL, Shaw PN, Davies NM. Preparation of immuno-stimulating complexes (ISCOms) by ether injection. Int J Pharm, 2006; 310:196-202.

115. McArthur J, Schulze K, Chin J, Currie BJ, Sriprakash KS, Talay SR, Chhatwal GS, Guzmán CA, Walker MJ. Immune responses of a liposome/ISCOM vaccine adjuvant against streptococcal fibronectin binding protein 1 (Sfb1) in mice. Indian J Med Res, 2004; 119:115-20.

116. Madsen HB, Arboe-Andersen HM, Rozlosnik N, Madsen F, Ifversen P, Kasimova MR, Nielsen HM. Investigation of the interaction between modified ISCOMs and stratum corneum lipid model systems. Biochim Biophys Acta (BBA) Biomembr 2010; 1798:1779-89.

117. Barrán-Berdón AL, Mónica M, Clara AR, Lourdes P, María-Rosa I, Castro-Hartmann P, Alberto M, Emilio A, Elena J. Ribbon-type and clustertype lipoplexes constituted by a chiral lysine based cationic gemini lipid and plasmid DNA. Soft Matter, 2012; 8:7368-7380.

118. Alevtina D, Sonya G, George C. Efficient delivery of transgenes to human hair follicle progenitor cells using topical lipoplex. Nat Biotechnol, 2000; 18:420-423.

119. San H, Yang ZY, Pompili VJ, Jaffe ML, Plautz $\mathrm{GE}$, $\mathrm{Xu} \mathrm{L}$, Felgner JH, Wheeler CJ, Felgner
PL, Gao X. Safety and short-term toxicity of a novel cationic lipid formulation for human gene therapy. Hum Gene Ther, 1993; 4:781-8.

120. Schwartz B, Ivanov MA, Pitard B, Escrioul V, Rangara R, Byk G, Wils P, Crouzetand DS. Synthetic DNA-compacting peptides derived from human sequence enhance cationic lipid-mediated genetransfer in vitro and in vivo. Gene Ther, 1999; 6:282-292.

121. Baichao M, Shubiao Z, Huiming J, Budiao Z, Hongtao L. Lipoplex morphologies and their influences on transfection efficiency in gene delivery.J Control Release, 2007; 123:184-194.

122. Mukherjee K, Sen J, Chaudhuri A. Common colipids, in synergy, impart high gene transfer properties to transfection-incompetent cationic lipids.FEBS Lett, 2005; 579:1291-300.

123. Khalil IA, Kogure K, Akita H, Harashima H. Uptake pathways and subsequent intracellular trafficking in nonviral gene delivery. Pharmacol Rev, 2006; 58:32-45.

124. Tan Y, Liu F, Li Z, Li S, Huang L. Sequential Injection of Cationic Liposome and Plasmid DNA Effectively Transfects the Lung with Minimal Inflammatory Toxicity. Mol Therap, 2001; 3:673682.

125. Audouy S, Hoekstra D. Cationic lipid-mediated transfection in vitro and in vivo (review). Mol Membr Biol, 2001; 18:129-143.

126. Hermanson G, Whitlow V, Parker S, Tonsky K, Rusalov D, Ferrari M, Lalor P, Komai M, Mere R, Bell M, Brenneman K, Mateczun A, Evans T, Kaslow D, Galloway D, Hobart P. A cationic lipid-formulated plasmid DNA vaccine confers sustained antibody-mediated protection against aerosolized anthrax spores.Proc Natl Acad Sci, USA, 2004; 101:13601-6.

127. Behfar M, Sarah E, Qinguo Z, Afzal RM, Yvonne P. Exploring the Correlation Between Lipid Packaging in Lipoplexes and Their Transfection Efficacy. Pharmaceutics, 2011; 3:848-864.

128. Yanasarn N, Sloat BR, Cui Z. Negatively charged liposomes show potent adjuvant activity when simply admixed with protein antigens. Mol Pharm, 2011; 8(4): 1174-1185.

129. Majeti BK, Karmali PP, Madhavendra SS, Chaudhuri A. Example of fatty acid-loaded lipoplex in enhancing in vitro gene transfer efficacies of cationic amphiphile. Bioconjug Chem, 2005; 16:676-84.

130. Kearns MD, Patel YN, Savva M. Physicochemical characteristics associated with transfection of cationic cholesterol-based gene delivery vectors in the presence of DOPE. Chem Phys Lipids, 2010; 163:755-64.

131. Dufaÿ WA, Hillaireau H, Nascimento TL, Arpicco $\mathrm{S}$, Taverna M, Ribes S, Bourge M, Nicolas V, 
Bochot A, Vauthier C, Tsapis N, Fattal E. Hyaluronic acid-bearing lipoplexes: Physicochemical characterization and in vitro targeting of the CD44 receptor. J Control Release,2012; 162:545-52.

132. Gaëlle B, Riccardo C, Jelena KT, Vincent D, Olivier C, Florence G, Claire W, Christine M. Ultra Magnetic Liposomes for MR Imaging, Targeting, and Hyperthermia. Langmuir, 2012; 28:11834-11842.

133. Nazila K, Andrew DM. Paramagnetic Liposome Nanoparticles for Cellular and Tumour Imaging. Int J Mol Sci, 2010; 11:1759-1776.

134. Frascione D, Diwoky C, Almer G, Opriessnig P, Vonach C, Gradauer K, Leitinger G, Mangge H, Stollberger R, Prassl R. Ultrasmall superparamagnetic iron oxide (USPIO)-based liposomes as magnetic resonance imaging probes. Int J Nanomed, 2012; 7:2349 - 2359.

135. Pallab P, Jyotsnendu G, Rinti B, Jayesh B, Dhirendra B. Preparation and characterization of manganese ferrite-based magnetic liposomes for hyperthermia treatment of cancer. J Magn Magn Mater, 2007; 311:208-15.

136. Esther A, Joachim K, Elisabeth M, Thomas S, Marcus T, Erik R. Triggered Release from Liposomes through Magnetic Actuation of Iron Oxide Nanoparticle Containing Membranes. Nano Lett, 2011; 11:1664-1670.

137. Strijkers GJ, Kluza E, Van Tilborg GA, Van der Schaft DW, Griffioen AW, Mulder WJ, Nicolay K. Paramagnetic and fluorescent liposomes for target-specific imaging and therapy of tumor angiogenesis. Angiogenesis, 2010; 3:161-73.

138. Drummond DC, Meyer O, Hong K, Kirpotin DB, Papahadjopoulos D. Optimizing liposomes for delivery of chemotherapeutic agents to solid tumors. Pharmacol Rev, 1999; 51:691-743.

139. Kamaly N, Kalber T, Kenny G, Bell J, Jorgensen $\mathrm{M}$, Miller AD. A novel bimodal lipidic contrast agent for cellular labelling and tumor MRI. Org Biomol Chem, 2010; 8:201-211.

140. Kikumori T, Kobayashi T, Sawaki M,Imai T. Anti-cancer effect of hyperther mia on breast cancer by magnetite nanoparticle-loaded antiHER2 immunoliposomes. Breast Cancer Res Treat, 2009; 113:435-41.

141. Shido Y, Nishida Y, Suzuki Y, Kobayashi T, Ishiguro N. Targeted hyperthermia using magnetite cationic liposomes and an alternating magnetic field in a mouse osteosarcoma model.J Bone Joint Surg Br, 2010; 92:580-5.

142. Anchal S, Pravin P. Recent Trends in Niosome as Vesicular Drug Delivery System. J Appl Pharm Sci, 2012; 2:20-32.

143. Nefise, O.S., Niosomes as nanocarrier systems: a review, in Reza MM, Nanomaterials and
Nanosystems for Biomedical Applications, Springer Netherlands, Dordrecht,67-81, 2007.

144. Hunter CA, Dolan TF, Coombs GH, Baillie AJ. Vesicular systems (niosomes and liposomes) for delivery of sodium stibogluconate in experimental murine visceral leishmaniasis. J Pharm Pharmacol, 1988; 40:161-5.

145. Yoshioka T, Sternberg B, Florence AT. Preparation and Properties of Vesicles (Niosomes) of Sorbitan Monoesters (Span-20, Span-40, Span60 And Span-80) And A Sorbitan Triester (Span85). Int J Pharm, 1994; 105: 1-6.

146. II.P. Sheena, U.V. Singh, R. Kamath, D.P. Uma, N. Udupa, Niosomal withaferin A, with better tumor efficiency. Indian J Pharm Sci, 1998; 60:45-8.

147. Moser P, Marchand AM, Labrude P, Handjani VRM, Vignerson C. Hemoglobin niosomes: Preparation, functional and physico-chemical properties, and stability. Pharma Acta Helv, 1989; 64:192-202.

148. Raja RA, Naresh GC, Pillai GK, Udupa N. Antiinflammatory activity of niosome encapsulated diclofenac sodium in arthritic rats. Indian $\mathrm{J}$ Pharmacol, 1994; 26:46-48.

149. Jayaraman SC, Ramachandran C, Weiner N. Topical delivery of erythromycin from various formulations: an in vivo hairless mouse study. $\mathrm{J}$ Pharm Sci, 1996; 85:1082-4.

150. Uchegbu IF, Double JA, Turton JA, Florence TA. Distribution, metabolism and tumoricidal activity of doxorubicin administered in sorbitan monostearate (Span 60) niosomes in the mouse. Pharm Res, 1995; 12:1019-24.

151. Luciani AA, Olivier JC, Clement O, Siauve N, Brillet PY, Bessoud B, Gazeau F, Uchegbu IF, Kahn E, Frija G, Cuenod CA. Glucosereceptor MR imaging of tumors: study in mice with PEGylated paramagnetic Niosomes. Radiology, 2004; 231:135-42.

152. Kawai N, Ito A, Nakahara Y, Futakuchi M, Shirai $\mathrm{T}$, Honda H, Kobayashi T, Kohri K.Anticancer effect of hyperthermia on prostate cancer mediated by magnetite cationic liposomes and immune-

response induction in transplanted syngeneic rats.Prostate, 1986;64:373-81

153. Baillie AJ, Coombs GH, Dolan TF, Laurie J. Nonionic surfactant vesicles, niosomes, as delivery system for the anti-leishmanial drug, sodium stibogluconate. J Pharm Pharmacol, 1986;38:5025 .

154. Arunothayanun P, Turton JA, Uchegbu IF,Florence AT. Preparation and in vitro/in vivo evaluation of luteinizing hormone releasing hormone (LHRH)-loaded polyhedral and 
spherical/tubular niosomes. J Pharm Sci, 1999; 88:34-8.

155. Malhotra M, Jain NK. Niosomes as Drug Carriers. Indian Drugs, 1994; 31:81-86.

156. Baillie AJ, Florence AT, Hume LR, Muirhead GT, Rogerson AJ.Studies in topical application of niosomally entrapped Nimesulide. J Pharm Pharmacol, 1985; 7:863-868.

157. Biswal S, Murthy PN, Sahu J, Sahoo P, Amir F. Vesicles of Non-ionic Surfactants (Niosomes) and Drug Delivery Potential. Int J Pharm Sci Nanotechnol, 2008; 1:1-8.

158. Jin Y, Wen J, Garg S, Liu D, Zhou Y, Teng L,Zhang W. Development of a novel niosomal system for oral delivery of Ginkgo Biloba extract. Int J Nanomed, 2013; 8:421-30.

159. Marsh M, Matlin K, Simons K, Reggio J, White J, Kartenbeck J, Helenius A. Are lysosomes a site of enveloped-virus penetration? Cold Spring Harbor Symp Quant Biol, 1982; 46:835-843.

160. White J, Matlin K, Helenius A. Infectious entry pathway of influenza virus in a canine kidney cell line. J Cell Biol, 1981; 89:674-679.

161. Puras G, Mashal M, Zarate J, Agirre M, Ojeda E, Grijalvo S, Eritja R, Diaz-Tahoces A, Navarrete GM, Triqueros MA, Fernandez E, Pedraz JL, A novel cationic niosome formulation for gene delivery to the retina. J Control Rel, 2014; 174:2736.

162. Tavano L, Gentile L, Rossi CO, Muzzalipo. Novel gel-niosomes formulations as multicomponent systems for transdermal drug delivery. Coll Surf B Biointerf, 2013; 110:281-288.

163. Schenkman S, Aranjo PS, Sesso A, Quina FH, Chaimovich H. A kinetic and structural study of two-step aggregation and fusion of neutral phospholipid vesicles promoted by serum albumin at low pH. Chem Phys Lipids, 1981; 28:165-180.

164. Garcia LAM,Shenkman S, Araujo PS,Chaimovich H. Fusion of small unilamellar vesicles induced by bovine serum albumin fragments. Braz J Med Biol Res, 1983; 16:89-96.

165. Min-Jung K, Hyo LJ, In-Ah L, In-Young K, Sung KL, Hyun-Ah C,Jin-Seok K. Preparation of $\mathrm{pH}-$ Sensitive, Long-Circulating and EGFR-Targeted Immunoliposomes. Arch Pharm Res2008; 31:539546.

166. Ashish G, Efrosini K. pH-Sensitive PEGylated Liposomes Functionalized With a FibronectinMimetic Peptide Show Enhanced Intracellular Delivery to Colon Cancer Cells.Curr Pharm Biotechno, 2011; 12:1135-1143.

167. Qiao-ling Z, Yi Z, Min G, Di-jia Y, Xiao-feng Z, Yang L, Jing-yu X, Ying W, Zong-lin G, Konglang $\mathrm{X}$, Ai-jun Z, Wei-liang $\mathrm{C}$, Lin-sen S, Xuenong Z, Qiang Z. Hepatocyte-Targeted Delivery Using $\mathrm{pH}-$ Sensitive Liposomes Loaded with
Lactosylnorcantharidin Phospholipid Complex: Preparation, Characterization, and Therapeutic evaluation In Vivo and In Vitro. Curr Med Chem, 2012; 19:5754-5763.

168. Jerome C, Milton BY, Leaf H. pH-sensitive liposomes: Acid-induced liposome fusion; (phosphatidylethanolamine/palmitoylhomocystein e/resonance energy transfer). Biophysics, 1984; 81:1715-1718.

169. Marina SA, Francisco JA, José AT, Antonio O.New pH-sensitive liposomes containing phosphatidylethanolamine and a bacterial dirhamnolipid. Chem Phys Lipids, 2011; 164:1623.

170. Drummond DC, Zignani M, Leroux JC. Current status of $\mathrm{pH}$-sensitive liposomes in drug delivery. Prog Lipid Res, 2000; 39:409-460.

171. Nataliya MS, Xin L, Barbora B, Andreas HF, Vyacheslav VS, Xin G. Fliposomes: pH-Sensitive Liposomes Containing a trans-2morpholinocyclohexanol-Based Lipid That Performs a Conformational Flip and Triggers an Instant Cargo Release in Acidic Medium. Pharmaceutics, 2011; 3:379-405.

172. Carvalho J, Vieira FP, De Melo VJ, Lopes MTP, Silveira JN, Ramaldes GA, Garnier-Suillerot A, Pereira-Maia EC, De Oliveira MC. Preparation and cytotoxicity of cisplatin-containing liposomes. Braz J Med Biol Res, 2007; 40:1149-1157.

173. Banerjee S, Sen K, Pal TK, Guha SK. Poly(styrene-co-maleic acid)-based $\mathrm{pH}$-sensitive liposomes mediate cytosolic delivery of drugs for enhanced cancer chemotherapy. Int J Pharm, 2012; 436:786-97.

174. Sérgio S, João NM, Cristina F, Nejat D, Maria CP. On the formulation of $\mathrm{pH}$-sensitive liposomes with long circulation times. Adv Drug Delivery Rev, 2004; 56:947-965.

175. Yuba E, Kojima C, Harada A, Tana, Watarai $\mathrm{S}$, Kono K. pH-Sensitive fusogenic polymermodified liposomes as a carrier of antigenic proteins for activation of cellular immunity. Biomaterials, 2010; 31(5):943-51.

176. Watarai S, Iwase T, Tajima T, Yuba E, Kono K. Efficiency of pH-Sensitive Fusogenic PolymerModified Liposomes as a Vaccine Carrier. Sci World J, 2013; 2013: 903234.

177. Wang HW, Jiang PL, Lin SF, Lin HJ, Ou KL, Deng WP, Lee LW, Huang YY, Liang PH, Liu DZ. Application of galactose-modified liposomes as a potent antigen presenting cell targeted carrier for intranasal immunization. Acta Biomaterialia, 2013; 9:5681-5688.

178. Yuba E, Tajima N, Yoshizaki Y, Harada A, Hayashi H, Kono K. Dextran derivative-based pHsensitive liposomes for cancer immunotherapy. Biomaterials, 2014; 35:3091-3101. 
179. Zheng Y, Liu X, Samoshina NM, Chertkov VA, Franz AH, Guo X, Samoshin VV. Fliposomes: $\mathrm{pH}$-controlled release from liposomes containing new trans-2-morpholinocyclohexanolbased amphiphiles that perform a conformational flip and trigger an instant cargo release upon acidification. Nat Prod Commun, 2012;7(3):353-8.

180. AV, Veselov IS, Chertkov VA, Yaroslavov AA, Grishina GV, Samoshina NM, Samoshin VV. Fliposomes: new amphiphiles based on trans-3,4bis(acyloxy)-piperidine able to perform a $\mathrm{pH}$ triggered conformational flip and cause an instant cargo release from liposomes. Tetrahedron Lett, 2013;54(41):5600-5604.

181. Carvalho AD, Vieira FP, De Melo VJ, Lopes MTP, Silveria JN, Ramaldes GA, GarnierSuillerot A, Pereira-Maia EC, De Oliveria MC. Preparation and Cytotoxicity of Cisplatincontaining Liposomes. Braz J Med Biol Res, 2007;40:1149-1157.

182. Garg A, Kokkoli E. pH sensitive PEGylated liposomes functionalized with fibronectin-mimetic peptide show enhanced intracellular delivery to colon cancer cells. Curr Pharm Biotechnol, 2011;12(8):1135-43.

183. Sakaguchi N, Kojima C, Harada A, Kono K. Preparation of pH-sensitive poly(glycidol) derivatives with varying hydrophobicities: their ability to sensitize stable liposomes to $\mathrm{pH}$. Bioconjugate Chem, 2008; 19:1040-48.

184. Yuba E, Harada A, Sakanishi Y, Kono K. Carboxylated hyperbranched poly(glycidol)s for preparation of $\mathrm{pH}$-sensitive liposomes. J Control Release, 2011; 149:72-80.

185. Juan L, Huili M, Tuo W, Xing-Jie L. $\mathrm{CO}_{2}$ gas induced drug release from $\mathrm{pH}$-sensitive liposome to circumvent doxorubicin resistant cells. Chem Comm, 2012; 48:4869-4871.

186. Regen SL, Singh A, Oehme G, Singh M. Polymerized phosphatidyl choline vesicles. Stabilized and controllable time-release carriers. Biochem Bioph Res Co, 1981; 101:131-136.

187. Qin G, Li Z, Xia R, Li F, O'Neill BE, Goodwin JT, Khan HA, Chiu W, Li KC. Partially polymerized liposomes: stable against lea kage yet capable of instantaneous release for remo te controlled drug delivery. Nanotechnology, 2011; 22:155605.

188. NoahF, Jason C, Jon ON, Elliot ML, McCabe K, Anna MW, Timothy T, Hyung GK, Bin L, James DM, Christopher TD. Enhanced Growth Inhibition of Osteosarcoma by Cytotoxic Polymerized Liposomal Nanoparticles Targeting the Alcam Cell Surface Receptor. Sarcoma, 2012; 2012:126906.
189. Städler B, Chandrawati R, Goldie K, Caruso F. Capsosomes: Subcompartmentalizing Polyelectrolyte Capsules Using Liposomes. Langmuir, 2009; 25:6725-6732.

190. Takeoka S, Ohno H, Hayashi N arid Tsuchida E. Control of release of encapsulated molecules from polymerized mixeci liposomes induced by physical or chemicd stimuli. J Control Re1 1989; 9:177-1 86 .

191. Sivakumar PA, Panduranga KR. Stable Polymerized Cholesteryl Methacrylate Liposomes for Vincristine Delivery. Biomed Microdevices, 2001; 3:143-148.

192. Smith CE, Kong H. Cross-Linkable Liposomes Stabilize a Magnetic Resonance ContrastEnhancing Polymeric Fastener. Langmuir, 2014, 30 (13), pp 3697-3704.

193. Roney CA, Xu B, Xie J, Yuan S, Wierwille J, Chen CW, Chen Y, Griffiths GL. Summers RM. Rh-I-UEA-1 polymerized liposomes target and image adenomatous polyps in the APC (Min/+) mouse using optical colonography. Mol Imaging, 2011; 10:305-16.

194. Hongming C, Vladimir T, Robert L. Polymerized liposomes as potential oral vaccine carriers: Stability and bioavailability. J Control Release, 1996; 42:263-272.

195. Amit K, Satya S, Meriong Z, Alison M, Chengzhi C. Localization of antimicrobial peptides on polymerized liposomes leading to their enhanced efficacy against Pseudomonas aeruginosa. Mol Biosys, 2011; 7:711-713.

196. Hongming C, Robert SL. Polymerized Liposomes Targeted to M Cells and useful for Oral or Mucosal Drug Delivery. U.S.Patents, US 6060082, 2000.

197. Chengzhi C, Guoting Q, Amit K. Compositions and methods for making and using multifunctional polymerized liposomes. U.S. Patents, US 20090162424, 2009.

198. Shiyong Z, Yan Z. Controlled Release from Cleavable Polymerized Liposomes upon Redox and $\mathrm{pH}$ Stimulation. Bioconjugate Chem, 2011; 22:523-528.

199. Amit K, Uriel JE, Guoting Q, King L, Chengzhi C. "Clickable" polymerized liposomes as a versatile and stable platform for rapid optimization of their peripheral compositions. Chem Comm, 2010; 46:5746-5748.

200. Cabral EC, Hennies PT, Correia CR, Zollner RL, Santana MH. Preparation and characterization of diacetylene polymerized liposomes for detection of autoantibodies. J Liposome Res, 2003; 13:199211.

201. Payne NI, Timmins P, Ambrose CV, Ward MD, Ridgway F. Proliposomes: a novel solution to an old problem. J Pharm Sci,1986; 75:325-9. 
202. Wang S, Ye T, Yang B, Yi X, Yao H. 7-Ethyl-10hydroxycamptothecin proliposomes with a novel preparation method: optimized formulation, characterization and in-vivo evaluation. Drug Dev Ind Pharm, 2013; 39:393-401.

203. Yan-yu X, Yun-mei S, Zhi-peng C, Qi-neng P. Preparation of silymarin proliposomes: A new way to increase oral bioavailability of silymarin in beagle dogs.Int Pharm, 2006; 319:162-8.

204. Sun C, Wang J, Liu J, Qiu L, Zhang W, Zhang L. Liquid proliposomes of nimodipine drug delivery system: preparation, characterization, and pharmacokinetics. AAPS PharmSciTech, 2013; 14(1):332-8.

205. Vandana G, Ashok KB, Suman R. Formulation Development and in vitro Characterization of Proliposomes for Topical Delivery of Aceclofenac. Indian J Pharm Sci, 2008; 70:768775.

206. Gupta V, Barupal AK, Ramteke S. Formulation development and in vitro characterization of proliposomes for topical delivery of Aceclofenac. Indian J Pharm Sci, 2008;70(6):768-775.

207. Byung-Nak A, Shin-Keun K, Chang-Koo S. Proliposomes as an intranasal dosage form for the sustained delivery of propranolol. J Control Release, 1995; 34:203-210.

208. Elhissi AMA, Taylor KMG. Delivery of liposomes generated from proliposomes using airjet, ultrasonic, and vibrating-mesh nebulizers. J Drug Del Sci Tech, 2005; 15:261-265.

209. Katare OP, Vyas SP, Dixit VK. Effervescent granule based proliposomes of ibuprofen. J Microencapsul, 1990; 7:455-62.

210. Sharan KRB, Prabhakar RV. Formulation, evaluation, and pharmacokinetics of isradipine proliposomes for oral delivery. J Liposome Res, 2012; 22:285-294.

211. Sarbolouki MN, Parsaee S, Kosary P. Mixed micelle proliposomes for preparation of liposomes containing amphotericin $\mathrm{B}$, in-vitro and ex-vivo studies. PDA J Pharm Sci Technol, 2000; 54:2406.

212. Janga KY, Jukanti R, Velpula A, Sunkavalli S, Bandari S, Kandadi P, Veerareddy PR. Bioavailability enhancement of zaleplon via proliposomes: Role of surface charge. Eur J Pharm Biopharm, 2012; 80:347-57.

213. Rojanarat $\mathrm{W}$, Nakpheng $\mathrm{T}$, Thawithong $\mathrm{E}$, Yanyium N, Srichana T. Inhaled pyrazinamide proliposome for targeting alveolar macrophages. Drug Deliv, 2012; 19:334-45.

214. Kono K. Thermosensitive polymer-modified liposomes. Adv Drug Del Rev, 2001; 53:307-319.

215. Needham D, Durham NC. Temperature-sensitive liposomal formulation. U. S. Patents, US 6200598, 2001.
216. Chong-Kook K, Suk-Kyeong L,Beom-Jin L. Preparation and evaluation of temperature sensitive liposomes containing adriamycin and cytarabine.Pharmacal Research, 1993; 16:129133.

217. Mark JE, Arthur W, Jonathan PM, Tatsuaki T, Michael CK, Shyh DL. Ultrasound drug targeting to tumors with thermosensitive liposomes. International Ultrasonics Symposium (IUS), 2011; 2011:1-4.

218. Needham D, Dewhirst MW. The development and testing of a new temperature-sensitive drug delivery system for the treatment of solid tumors. Adv Drug Delivery Rev, 2001; 53:285-305.

219. Needham D, Park JY, Wright AM, Tong J. Materials characterization of the low temperature sensitive liposome (LTSL): effects of the lipid composition (lysolipid and DSPEPEG2000) on the thermal transition and release of doxorubicin. Faraday Discuss, 2013; 161:515534.

220. Al-Jamal, Wafa T, Al-Ahmady, Zahraa S, Kostarelos K. Pharmacokinetics \& tissue distribution of temperature-sensitive liposomal doxorubicin in tumor-bearing mice triggered with mild hyperthermia. Biomaterials, 2012; 33:46084617.

221. David N, Gopal A, Garheng K, Mark WD. A New Temperature-sensitive Liposome for Use with Mild Hyperthermia: Characterization and Testing in a Human Tumor Xenograft Model. Cancer Res, 2000; 60:1197-201.

222. de Smet M, HijnenNM, Langereis S, Elevelt A, Heijman E, Dubois L, Lambin P, Grüll H. Magnetic Resonance Guided High-Intensity Focused Ultrasound Mediated Hyperthermia Improves the Intratumoral Distribution of Temperature-Sensitive Liposomal Doxorubicin. Invest Radiol, 2013; 48:395-405.

223. Ahmed M, Liu Z, Lukyanov AN, Signoretti S, Horkan C, Monsky WL, Torchilin VP, Goldberg SN. Combination radiofrequency ablation with intratumoral liposomal doxorubicin: effect on drug accumulation and coagulation in multiple tissues and tumor types in animals. Radiology, 2005; 235:469-77.

224. Benjamin LV, Sheela A, Charles RM, Pavel SY, James RM, Marcel BB, Mark WD. In Vivo Monitoring of Tissue Pharmacokinetics of Liposome/Drug Using MRI: Illustration of Targeted Delivery. Magn Reson Med, 2004; 51:1153-1162.

225. Grüll H, Langereis S. Hyperthermia-triggered drug delivery from temperature-sensitive liposomes using MRI-guided high intensity focused ultrasound. J Control Release, 2012; 161:317-27. 
226. Li L, ten Hagen TLM, Haeri A, Soullie T, Scholten C, Seynhaeve ALB, Eggermont AMM, Koning GA. A novel two-step mild hyperthermia for advanced liposomal chemotherapy. J Control Rel, 2014; 174: 202-208.

227. Ravi K, Manvir S, Rajni B, Nimrata S, Rana AC. Comparison of novel vesicular system (transferosomes, niosomes) for transdermal drug delivery. Int J Nat Prod Sci, 2012; 1:64.

228. Gregor C, Dieter G. Hydration-Driven Transport of Deformable Lipid Vesicles through Fine Pores and the Skin Barrier. Biophys J, 2003; 84:10101024.

229. Rajan R, Vasudevan DT. Effects of permeation enhancers on the permeation mechanism of transferosomal gel of ketoconazole. J Adv PharmTechRes, 2012; 3:112-6.

230. Shailesh TP, Charmi GP,Chhagan NP. Transferosomes: A vesicular carrier system for transdermal drug delivery. Asian $\mathrm{J}$ Biochem Pharm Res, 2011; 1:507-524.

231. Ceve G. Transdermal drug delivery of Insulin with ultradeformable carriers. Clin Pharmacokinet, 2003; 42:461-174.

232. Ceve G, Blume G. Biological activity and characteristics of triamcinolone-acetonide formulated with the self-regulating drug carriers Transfersomes. Biochim Biophys Acta, 2003; 1614:156-64.

233. Maghraby GM, Williams AC, Barry BW. Skin delivery of estradiol from deformable and traditional liposomes: mechanistic study. J pharm pharmacol, 1999; 51:1123-1124.

234. Garg M, Mishra D, Agashe H, Jain NK. Ethinylestradiol loaded ultraflexible liposomes: Pharmackinetics and Pharmacodynmics. J Pharm Pharmacol, 2006; 58:459-468. 